University of Wollongong

Research Online

Faculty of Engineering and Information

Faculty of Engineering and Information

Sciences - Papers: Part A

Sciences

$1-1-2013$

\title{
Analyses of reinforced embankment on soft and hard foundations
}

Sowarapan Duangkhae

Asian Institute of Technology

Dennes Bergado

Asian Institute of Technology

Pankaj Baral

University of Wollongong, pb994@uowmail.edu.au

Barry T. Ocay

Asian Institute of Technology

Follow this and additional works at: https://ro.uow.edu.au/eispapers

Part of the Engineering Commons, and the Science and Technology Studies Commons

Research Online is the open access institutional repository for the University of Wollongong. For further information contact the UOW Library: research-pubs@uow.edu.au 


\title{
Analyses of reinforced embankment on soft and hard foundations
}

\author{
Abstract \\ In this paper, the analyses and design using conservative limit equilibrium methods (AASHTO simplified \\ and FHWA structure stiffness methods) were compared with the working stress methods called K- \\ stiffness method (original and modified K-stiffness methods). Moreover, the predictions from the K- \\ stiffness methods were confirmed from the observed data for a reinforced embankment on a hard \\ foundation. Furthermore, since the reinforcement loads increased due to post-construction settlements \\ for reinforced embankments on soft foundation, a further modification of the K-stiffness method is \\ proposed. This further modification is concerned with the proposed settlement factor. The validity of this \\ further modification is demonstrated by the good agreement between the maximum measured \\ reinforcement loads and the recalculated maximum reinforcement loads from further modified K- \\ stiffness method. \\ Keywords \\ hard, analyses, foundations, reinforced, soft, embankment \\ Disciplines \\ Engineering | Science and Technology Studies \\ Publication Details \\ Duangkhae, S., Bergado, D. T., Baral, P. \& Ocay, B. T. (2013). Analyses of reinforced embankment on soft \\ and hard foundations. Proceedings of the Institution of Civil Engineers: Ground Improvement, 167 (1), \\ 2-23.
}

This journal article is available at Research Online: https://ro.uow.edu.au/eispapers/2191 


\section{Analyses of reinforced embankment on soft and hard foundations}

1 Sowarapan Duangkhae DEng Doctoral candidate, School of Engineering and Technology, Asian Institute of Technology, Klongluang, Pathumthani, Thailand

2. Dennes T. Bergado PhD

Professor, School of Engineering and Technology, Asian Institute of Technology, Klongluang, Pathumthani, Thailand
3 Pankaj Baral MEng

Research assistant, School of Engineering and Technology, Asian Institute of Technology, Klongluang, Pathumthani, Thailand

4 Barry T. Ocay MEng

Graduate, School of Engineering and Technology, Asian Institute of Technology, Klongluang, Pathumthani, Thailand
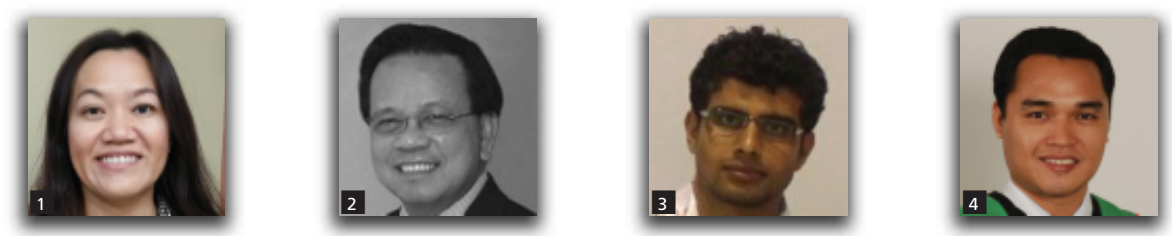

In this paper, the analyses and design using conservative limit equilibrium methods (AASHTO simplified and FHWA structure stiffness methods) were compared with the working stress methods called K-stiffness method (original and modified K-stiffness methods). Moreover, the predictions from the K-stiffness methods were confirmed from the observed data for a reinforced embankment on a hard foundation. Furthermore, since the reinforcement loads increased due to post-construction settlements for reinforced embankments on soft foundation, a further modification of the K-stiffness method is proposed. This further modification is concerned with the proposed settlement factor $\left(\Phi_{s}\right)$. The validity of this further modification is demonstrated by the good agreement between the maximum measured reinforcement loads and the recalculated maximum reinforcement loads from further modified K-stiffness method.

\section{Notation}

Basic SI units are given in parentheses.

c soil cohesion $(\mathrm{kPa})$

$D_{\text {tmax }} \quad$ reinforcement load distribution factor (dimensionless)

$H \quad$ height of wall (m)

$J \quad$ average tensile stiffness of reinforcement $(\mathrm{kN} / \mathrm{m})$

$K \quad$ coefficient of lateral earth pressure (dimensionless)

$q \quad$ surcharge pressure $\left(\mathrm{kN} / \mathrm{m}^{2}\right)$

$S \quad$ equivalent soil height of uniform surcharge load

$S_{\mathrm{r}} \quad$ global reinforcement stiffness

$S_{\mathrm{V}} \quad$ tributary area for reinforcement layer (m)

$T_{\max } \quad$ maximum reinforcement load $(\mathrm{kN} / \mathrm{m})$

$\gamma \quad$ unit weight of soil $\left(\mathrm{kN} / \mathrm{m}^{3}\right)$

$\Phi_{\mathrm{c}} \quad$ soil cohesion factor (dimensionless)

$\Phi_{\mathrm{cs}} \quad$ combined cohesion and settlement factor (dimensionless)

$\Phi_{\mathrm{fb}} \quad$ face batter factor (dimensionless)

$\Phi_{\mathrm{fs}} \quad$ facing stiffness factor (dimensionless)

$\Phi_{\mathrm{g}} \quad$ global stiffness factor (dimensionless)

$\Phi_{\text {local local stiffness factor (dimensionless) }}$

$\Phi_{\mathrm{ps}} \quad$ plane strain friction angle

$\Phi_{\mathrm{tx}} \quad$ peak triaxial friction angle

$\Omega_{1} \quad$ dimensionless coefficient equal to $1 \cdot 0$ for strip and sheet reinforcement or equal to 1.5 for geogrid and welded wire mats

$\Omega_{2} \quad$ dimensionless coefficient equal to $1 \cdot 0$ if $S_{\mathrm{r}} \leqslant 47880 \mathrm{kPa}$ or $\Omega_{2}=\Omega_{1}$ if $S_{\mathrm{r}}>47880 \mathrm{kPa}$

\section{Introduction}

To assess the internal stability design of geosynthetic- and steelreinforced soil walls, appropriate estimations of soil reinforcement loads and deformations are necessary. The predicted reinforcement loads influence the strength and spacing needed for the reinforcement as well as the reinforcement length to resist pullout. Two limit equilibrium methods can be found in recent North American design specifications to estimate reinforcement loads: (a) the tieback wedge/simplified method (AASHTO, 2002), and $(b)$ the Federal Highway Administration (FHWA) structure stiffness method (Christopher et al., 1990). Current design methodologies use limit equilibrium concepts to calculate reinforcement loads. A new working stress analytical method called the K-stiffness methods, both the original method (Allen et al., 2003) and the modified method (Miyata and Bathurst, 2007a), have been proposed as alternatives of the conservative limit equilibrium methods. The K-stiffness method has been modified by Tin et al. (2011) combining the effects of cohesion and 
settlements. The content of this paper confirms the validity of the K-stiffness method for a reinforced embankment on hard foundation and compares the corresponding performance of reinforced embankments on a soft foundation. Moreover, further modifications of the K-stiffness method were made by investigating the effects of cohesion and settlement factors separately.

\section{AASHTO simplified and FHWA structure stiffness methods}

In the tieback wedge or simplified method (AASHTO, 2002), the wall is assumed to be flexible enough with deformation to achieve an active state of stress. The lateral earth pressure coefficient $K_{\mathrm{a}}$ was determined with a horizontal backslope and no wall-soil interface friction in all cases. Polymer strap walls and walls with a face inclination less than $70^{\circ}$ from the horizontal were not included in this method. The maximum load, $T_{\max }$, in the reinforcement layer per unit width is indicated in Equation 1

1. $T_{\max }=S_{\mathrm{v}} K_{\mathrm{a}}[\gamma(z+S)+q]$

where $S_{\mathrm{v}}$ is the tributary area for reinforcement layer, $K_{\mathrm{a}}$ is the coefficient of active earth pressure, determined with a horizontal backslope and no wall-soil interface friction, $\gamma$ is the unit weight of the soil, $z$ is the depth of reinforcement layer below the top of the wall, $S$ is the equivalent soil height of uniform surcharge pressure and $q$ is the surcharge pressure.

In the FHWA structure stiffness method (Christopher et al., 1990), the active earth pressure coefficient, $K_{\mathrm{a}}$, is increased by a factor which is dependent on the depth below the wall crest, reinforcement type, and global wall stiffness. The maximum load, $T_{\max }$ in the reinforcement layer per unit width is given in Equation 2

2. $T_{\max }=S_{\mathrm{v}} K_{\mathrm{r}}[\gamma(z+S)+q]$

$$
\begin{aligned}
& K_{\mathrm{r}}=K_{\mathrm{a}}\left[\Omega_{1}\left(1+0 \cdot 4 \frac{S_{\mathrm{r}}}{47880}\right)\left(1-\frac{z}{6}\right)+\Omega_{2} \frac{z}{6}\right] \\
& \text { if } z(\mathrm{~m}) \leqslant 6 \mathrm{~m}
\end{aligned}
$$

$K_{\mathrm{r}}=K_{\mathrm{a}} W_{2} \quad$ if $z(\mathrm{~m})>6 \mathrm{~m}$

$S_{\mathrm{r}}=J /(H / n)$ in units of $\mathrm{kN} / \mathrm{m}^{2}$

where $K_{\mathrm{r}}$ is the lateral earth pressure coefficient, $S_{\mathrm{r}}$ is the global reinforcement stiffness for the wall, $\Omega_{1}$ is the dimensionless coefficient equal to 1.0 for strip and sheet reinforcement or equal to 1.5 for geogrid and welded wire mats, $\Omega_{2}$ is the dimensionless coefficient equal to 1.0 if $S_{\mathrm{r}} \leqslant 47880 \mathrm{kPa}$ or $\Omega_{2}=\Omega_{1}$ if $\Omega_{\mathrm{r}}>47880 \mathrm{kPa}, J$ is the average reinforcement stiffness for the wall (in units of force per running unit length of wall) and $H / n$ is the average vertical spacing of the reinforcement ( $H$ is the height of the wall and $n$ is the total number of reinforcement layers).

Allen and Bathurst (2002) made a comparison of predicted and estimated loads and the results are illustrated in Figure 1. The data showed that there was a large amount of scatter. Moreover, the general trend was that the predicted loads using the American Association of State Highway and Transportation Officials (AASHTO) simplified method were greater than the estimated loads except for two walls GW7 and GW19 which were a slope-face wall ( $27^{\circ}$ facing batter) and a polyester (PET) strap-reinforced soil wall, respectively. However, heavily sloped walls and stiff polymer strap walls were not allowed in the simplified method (AASHTO, 2002).

\section{Original and modified K-stiffness methods}

The aforementioned limit equilibrium methods were found to be excessively conservative based on the performance of reinforced

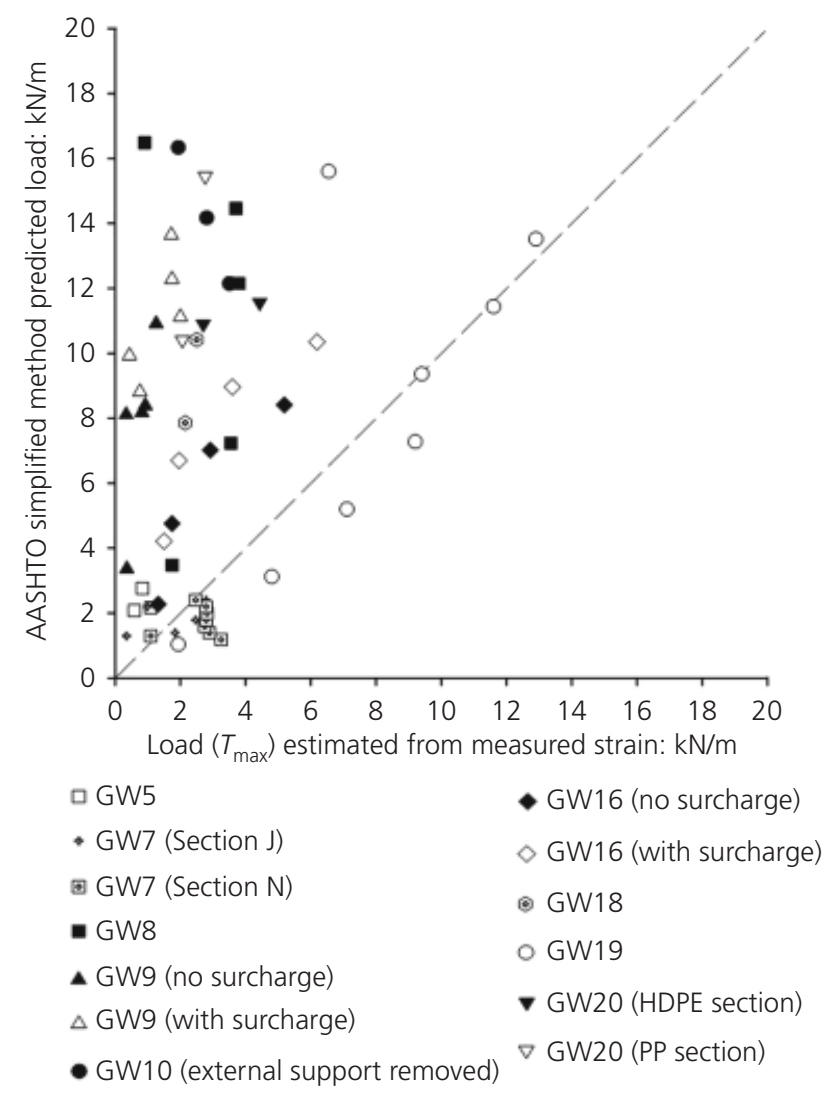

Figure 1. Predicted versus measured values of $T_{\max }$ in reinforcement layers for geosynthetic walls using the ASSHTO Simplified Method and peak plane strain soil friction angles (Allen and Bathurst, 2002). HDPE, high-density polyethylene;

PP, polypropylene 
walls/embankments. To overcome the poor performance of these methods, Allen et al. (2003) presented a new method called the $\mathrm{K}$-stiffness method to estimate reinforcement loads in geosynthetic walls constructed with granular (noncohesive, relatively low silt content) more accurately in order to decrease the reinforcement quantities and improve the economy of geosynthetic walls. Allen et al. (2004) extended this original method to apply for steel-reinforced structures. The maximum reinforcement load, $T_{\max }$, in a layer on per unit width basis is calculated in Equation 3

$$
T_{\max }=\frac{1}{2} K \gamma(H+S) S_{\mathrm{v}} D_{\mathrm{tmax}} \Phi_{\mathrm{g}} \Phi_{\text {local }} \Phi_{\mathrm{fs}} \Phi_{\mathrm{fb}}
$$

where $K$ is the lateral earth pressure coefficient; $\gamma$ is the unit weight of the soil; $H$ is the height of the wall; $S$ is the equivalent height of uniform surcharge pressure $q$ (i.e. $S=q / \gamma$ ); $S_{\mathrm{v}}$ is the tributary area (equivalent to the vertical spacing of the reinforcement in the vicinity of each layer when analyses are carried out per unit length of wall); $D_{\operatorname{tmax}}$ is the load distribution factor that modifies the reinforcement load based on the layer location as shown in Figure 2(a) for geosynthetic-reinforced wall and Figure 2(b) for steel-reinforced wall; $\Phi_{\mathrm{g}}, \Phi_{\text {local }}, \Phi_{\mathrm{fs}}, \Phi_{\mathrm{fb}}$ are the influence factors that account for the effects of global and local reinforcement stiffness, facing stiffness and face batter, respectively.

Miyata and Bathurst (2007b) adjusted the calculation of facing stiffness factor considered in the original K-stiffness method, which resulted in the improvement of the prediction of reinforcement load by original K-stiffness method. Moreover, Miyata and Bathurst (2007a) added the cohesion influence factor into the original K-stiffness method to apply for the case of cohesive backfill soil as indicated in Equation 4

4. $\quad T_{\max }=\frac{1}{2} K \gamma(H+S) S_{\mathrm{v}} D_{\text {tmax }} \Phi_{\mathrm{g}} \Phi_{\text {local }} \Phi_{\mathrm{fs}} \Phi_{\mathrm{fb}} \Phi_{\mathrm{c}}$

where $\Phi_{\mathrm{c}}=1-\lambda(c / \gamma H)$ is the cohesion factor. For the cohesion coefficient $\lambda=6.5$ then $c / \gamma \mathrm{H} \leqslant 0.153$ is required. From more full-scale field tests, Bathurst et al. (2008) calibrated previous versions of the K-stiffness method by improving the expression of facing stiffness factor $\left(\Phi_{\mathrm{fs}}\right)$. Both original and modified $\mathrm{K}$ stiffness methods can only be applied for reinforced structures constructed on a stiff foundation. Nowadays, some constructions have been built on soft ground with large settlement which can be up to more than $1 \mathrm{~m}$. These constructions have still presented good performance since the current design methods have given excessive reinforcement loads compared to the K-stiffness method. The state-of-the-art methods do not mention the influence of settlement on reinforcement load of reinforced structures constructed on soft ground.

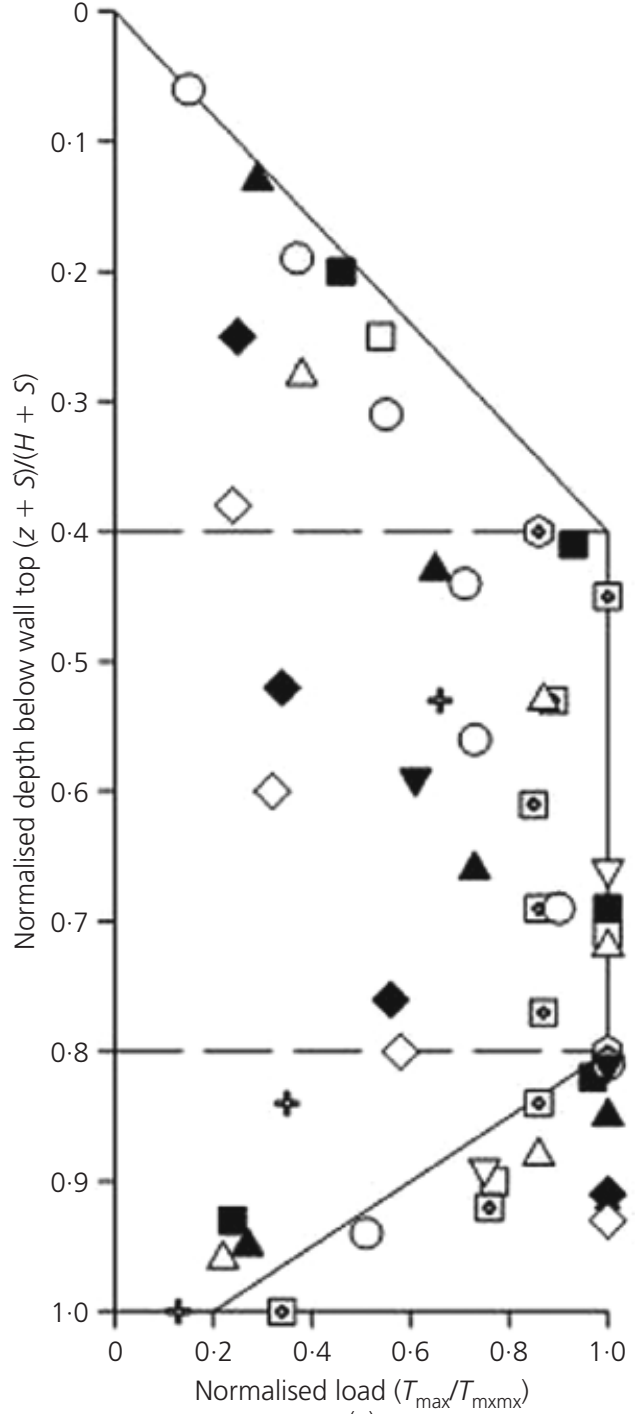

(a)

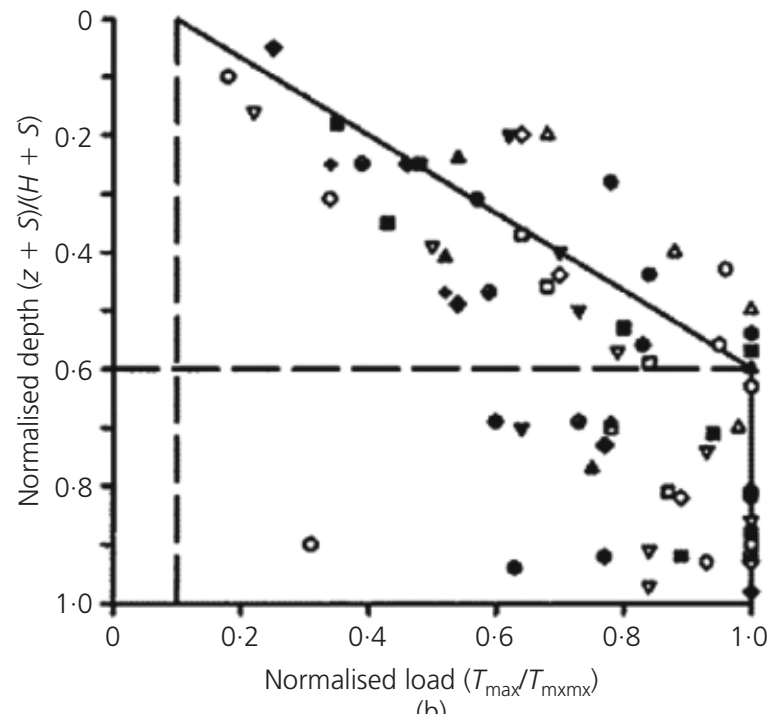

(b)

Figure 2. Distribution of $D_{\text {tmax }}$ (Allen et al., 2004).

(a) Geosynthetic-reinforced structure; (b) steel-reinforced structure 
In the present study, the investigation of the accuracy of the simplified method (AASHTO, 2002), FHWA structure stiffness method, original K-stiffness method (Allen et al., 2004) and modified K-stiffness method (Miyata and Bathurst, 2007a) to estimate the reinforcement load of mechanically stabilised earth (MSE) structures constructed on soft foundation will be presented. Moreover, the modification of the original K-stiffness method will also be given to consider the influence of settlements on the reinforcement loads. The influences of the variations of the other factors of the K-stiffness method such as $\Phi_{\text {local }}, \Phi_{\mathrm{fs}}$ and $\Phi_{\mathrm{fb}}$ have not been included.

Tin (2009) and Tin et al. (2011) modified the K-stiffness method which is used to calculate the reinforcement load of MSE structures on hard foundation and investigated its potential application for reinforced structures on soft ground. Jones and Edwards (1980) as well as Jones (1996) also explained the increased reinforcement strains and stresses for embankments on soft ground due to settlements. First, the current design methods for estimation of reinforcement loads of reinforced structures on hard ground, namely the tieback wedge or simplified method (AASHTO, 2002), FHWA structure stiffness method, original $\mathrm{K}$-stiffness method and modified K-stiffness method were applied to calculate the reinforcement load of the previous embankments of Bergado et al. (1991a, 1991b), Bergado et al. (2000) and Voottipruex (2000) constructed on soft ground at the Asian Institute of Technology (AIT) campus. From the comparison of calculated and observed values, the modification of original Kstiffness method was created by suggesting the uniform distribution of the reinforcement load and adding one more factor, the combined settlement and cohesion factor, $\Phi_{\mathrm{cs}}$, to consider the influence of settlement on the reinforcement load.

\section{Test embankments on deep mixing method improved soft foundation and hard foundation}

\subsection{Reinforced embankment on deep mixing method improved soft ground foundation}

A $6 \mathrm{~m}$ high vertical reinforced soil test embankment with total vertical surface area of $120 \mathrm{~m}^{2}$ and plan layout dimension of $19 \mathrm{~m}$ long by $6 \mathrm{~m}$ wide was constructed at Wangnoi District of Ayuthaya province situated $35 \mathrm{~km}$ north of the AIT campus in Thailand (Lai, 2009; Lai et al., 2006). The embankment was backfilled with silty sand material and reinforced with hexagonal wire mesh strips. Vertical precast concrete panels having a dimension of $1.5 \mathrm{~m} \times 1.5 \mathrm{~m} \times 0.15 \mathrm{~m}$ per panel/element was utilised as facing material of the wall. The compressible foundation of the embankment was improved by deep mixing method cement-clay piles using a jet grouting pressure of $20 \mathrm{MPa}$. Circular soil-cement piles with $0.6 \mathrm{~m}$ diameter were installed at $1.5 \mathrm{~m}$ spacing at the middle section and $2 \mathrm{~m}$ spacing at the edge portion of the embankment in a square pattern. An extensive field instrumentation programme was employed to observe the behaviour and performance of the embankment and its foundation. The section view of the embankment and location of instrumentations are shown in Figure 3. The foundation loads and settlements of the embankment at the ground surface are plotted in Figure 4.

\subsection{Reinforced embankment on hard foundation}

A full-scale reinforced earth embankment was designed and constructed by the Thailand Department of Highways and studied by Nualkliang (2011). The site of construction is near Highway No.11 in Phitsanulok, Thailand. The backfill soil consisted of $50 \%$ lateritic soil and $50 \%$ silty sand with effective cohesion of 5 to $20 \mathrm{kPa}$ and effective friction angle $37^{\circ}$ measured from consolidated undrained (CU) tension triaxial tests. One side was reinforced with a steep slope of $70^{\circ}$ from the horizontal, called reinforced soil slope (RSS) with soil bag facing. The other consisted of a mechanically stabilised earth wall (MSEW) with concrete panel facing. The RSS and MSEW test embankment were designed to $6 \mathrm{~m}$ height, $15 \mathrm{~m}$ width and $18 \mathrm{~m}$ length. On the side of the RSS three different types of polymeric geogrids reinforcement were installed, namely: polypropylene (PP), highdensity polyethylene (HDPE) and polyester (PET). On the other side, the MSEW was constructed with two types of metallic reinforcements such as metallic strip (MS) and steel wire grid (SWG). The polymer and metallic reinforcements are shown in Figure 5. The vertical spacing between each reinforcement layer was $0.5 \mathrm{~m}$ and the length was $5 \mathrm{~m}$ (upper layers of metallic strip from layer 7 to layer 12 have $5.80 \mathrm{~m}$ length). The monitoring instruments are shown in Figures 6 and 7 in plan and section views, respectively, consisting of inclinometers, strain gauges, piezometers, plate settlements and pressure cells. The strain gauges in the metallic reinforcements consist of vibrating wire strain gauges while fibre optic was utilised in the polymer reinforcements. The hard foundation consists of interlayering of dense to very dense sand and very stiff to hard clay. The embankment was constructed to $6 \mathrm{~m}$ height for 125 days. Subsequently, a surcharge of $20 \mathrm{kPa}(1.2 \mathrm{~m}$ thick) was added until 186 days after construction as shown in Figure 7. The vertical settlements are plotted across the section with PET and SWG reinforcements of the embankment as shown in Figure 8. A sensitivity analysis varying the effective cohesion, such as 5,10 and $15 \mathrm{kPa}$, was performed, which indicated that $10 \mathrm{kPa}$ confirmed the predictions.

\section{Previous test embankments on unimproved soft ground foundations}

The data obtained previously from two test embankments constructed on unimproved soft Bangkok clay at AIT campus were used for validation of the original and modified K-stiffness method by Tin (2009) and Tin et al. (2011). One embankment was reinforced with steel grids with three types of backfill materials consisting of clayey sand (CS), lateritic soil (LS) and weathered clay (WC) as briefly described in Section 5.1. The other was reinforced with two types of hexagonal reinforcement with silty sand backfill as briefly described in Section 5.2. Details of this embankment have been described by Tin (2009) and Tin et al. (2011). 


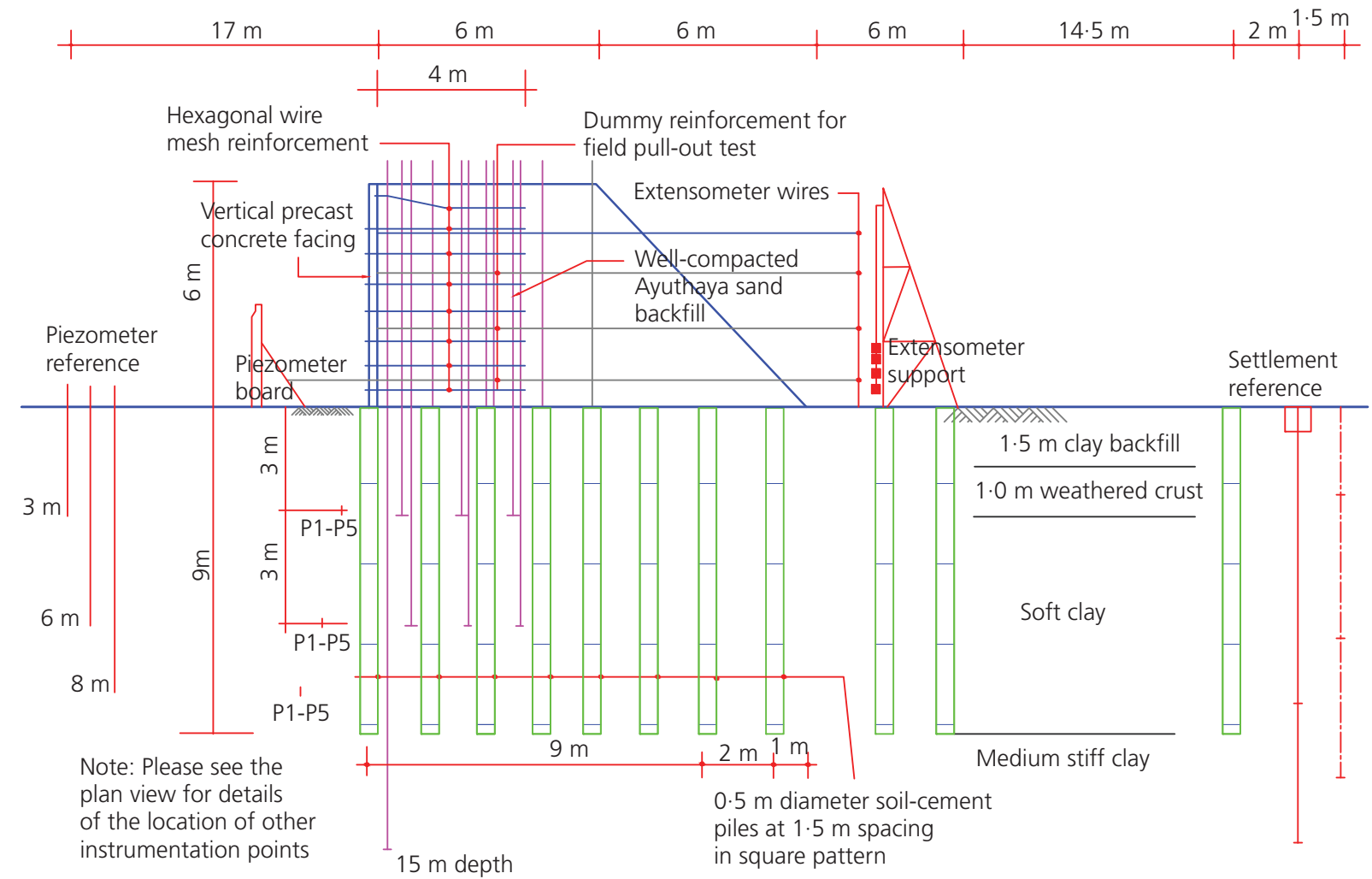

Section of MSE embankment

Figure 3. Full schematic diagram of the instrumentation programme at test embankment (Lai, 2009; Lai et al., 2006). MSE, mechanically stabilised earth

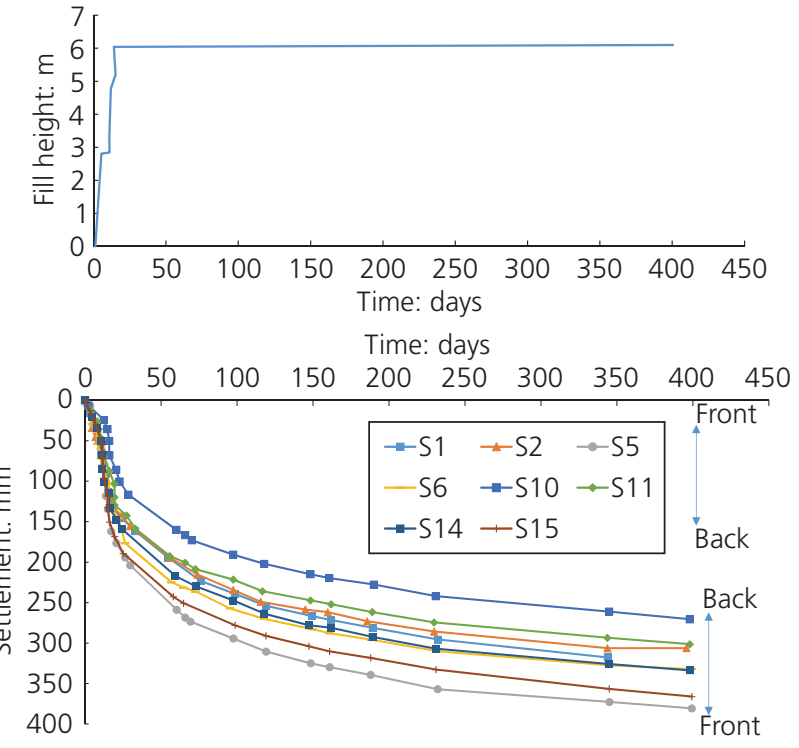

Figure 4. Foundation loads and settlements with time on ground and on piles near the centre of embankment (Lai, 2009; Lai et al., 2006). Note: Solid symbols on piles; hollow symbols on clay between piles)

\subsection{Steel grid-reinforced wall/embankment}

Shivashankar (1991) and Bergado et al. (1991a, 1991b) observed the behaviour of a welded wire wall with poor-quality, cohesivefriction backfills on soft Bangkok clay. The wall with a vertical wire mesh facing had a height of $5.7 \mathrm{~m}$, a length of $14.64 \mathrm{~m}$ at the top and was divided into three sections along its length (Figure 9). The welded wire mats were $2.44 \mathrm{~m}$ wide and $5.0 \mathrm{~m}$ long and consisted of W4.5 $\times \mathrm{W} 3.5(6.07 \mathrm{~mm} \times 5.36 \mathrm{~mm}$ diameter) size bars with 6 in $\times 9$ in $(0.15 \mathrm{~m} \times 0.225 \mathrm{~m})$ grid opening. There were seven mats instrumented with self-temperature compensating electrical resistant strain gauges for each section (Figure 10). The vertical spacing between the reinforcement mats was $0.45 \mathrm{~m}$. The backfill soil parameters as tabulated in Table 1 were deduced from consolidated isotropically undrained (CIU) tests (Bergado et al., 1991a, 1991b). The reinforcement tensions immediately after construction for the three types of backfill consisting of CS, LS and WC were similar. Figure 11 shows the typical values of reinforcement tension for clayey sand backfill. Moreover, the surface settlements were also observed as plotted in Figure 12. The settlement profiles are also plotted at the bottom of Figure 11. The soil profile of the embankment foundation consisted of the uppermost $2.0 \mathrm{~m}$ thick weathered clay layer underlain by a $6.0 \mathrm{~m}$ thick soft clay layer and followed by a 
Analyses of reinforced embankment on

soft and hard foundations

Duangkhae, Bergado, Baral and Ocay

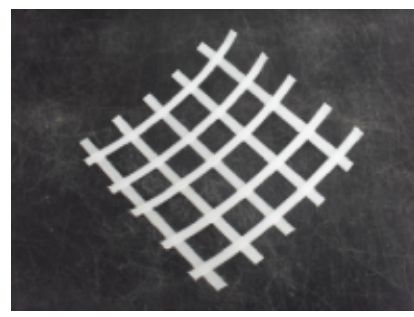

PP

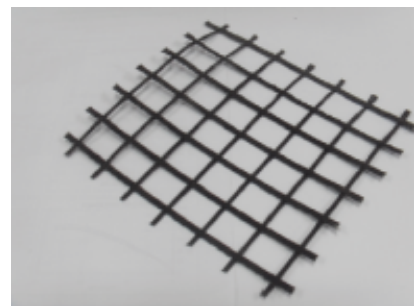

PET

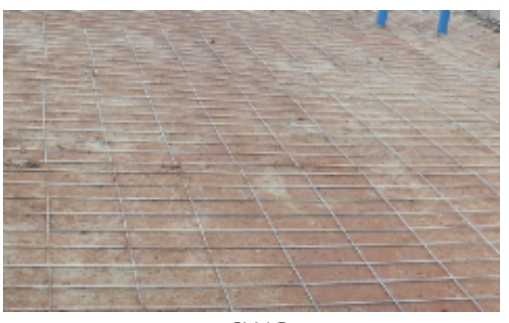

SWG

Figure 5. Polymer and metallic reinforcing materials. HDPE, high-density polyethylene; MS, metallic strip; PET, polyester; PP, polypropylene; SWG, steel wire grid

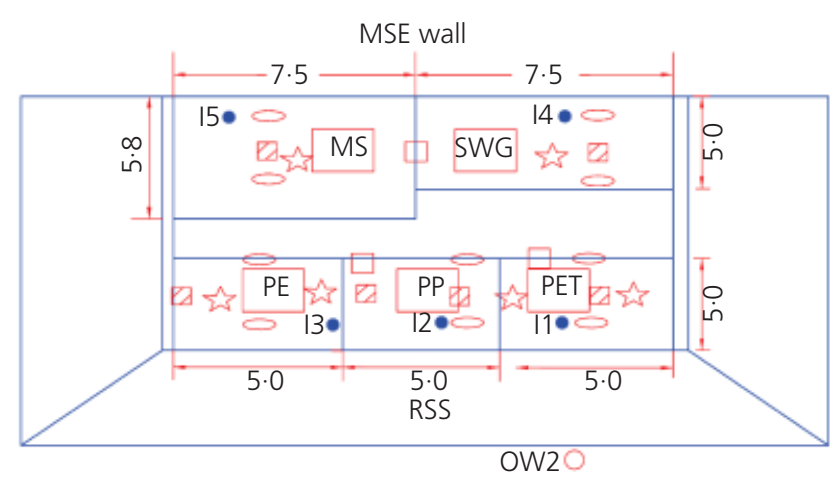

- 11-15 Inclinometer is TP1-TP6 Total pressure cell

$\checkmark$ S1-S45 Settlement plate $\triangle$ RB1-RB2 Reference benchmark OW1-OW2 Observation well $\square$ SP1-SP3 Standpipe piezometer $\square$ SD1-SD24 Strain gauge (dimensions in $\mathrm{m}$ )

Figure 6. Plan of MSE wall/embankment. MS, metallic strip, MSE, mechanically stabilised earth; PE, polyethylene;

PP, polypropylene; PET, polyester; RSS, reinforced soil slope; SWG, steel wire grid
$6.0 \mathrm{~m}$ thick stiff clay layer. The strength and compressibility parameters are given in Bergado et al. (2000) and Bergado and Teerawattanasuk (2008).

\subsection{Hexagonal wire mesh-reinforced wall}

Voottipruex (2000) and Bergado et al. (2000) investigated the behaviour of a full-scale embankment built at the AIT campus reinforced with hexagonal wire grids up to $6 \mathrm{~m}$ high with a $10^{\circ}$ slope of gabion facing as shown in Figure 13. The facing consisted of large rectangular wire baskets with dimensions $1 \mathrm{~m}$ by $1 \mathrm{~m}$ in cross-section linked together and filled with rocks. Two types of hexagonal wire reinforcements, namely zinc-coated and PVC-coated wire with different apertures, were used in two different sections along the length of the wall; and the vertical spacing between the reinforcement layers was $0.5 \mathrm{~m}$. The silty sand backfill was found to have an effective internal friction angle of $30^{\circ}$ and effective cohesion intercept of $5 \mathrm{kPa}$ as tabulated in Table 1 (Bergado and Teerawattanasuk, 2008; Bergado et al., 2000). The strength parameters were deduced from CIU triaxial tests with soil specimen compacted at maximum dry density $\left(\gamma_{\mathrm{dmax}}=18 \mathrm{kN} / \mathrm{m}^{3}\right)$ and optimum moisture content $(w=13 \%)$. The foundation subsoil layers were similar to the previously mentioned steel grid-reinforced embankment. The tensions in the PVC-coated hexagonal wires with distance from the back face of the wall after construction are given in Figure 14. Moreover, the corresponding surface settlements were also observed for a period of 400 days as plotted in Figure 15.

\section{Comparison of predicted reinforcement loads from different methods}

Predictions of reinforcement loads were made using limit equilibrium methods, namely the simplified method (AASHTO, 2002), and the FHWA structure stiffness method (Christopher et al., 1990) as described in Section 2. Furthermore, the original K-stiffness method (Allen et al., 2004) and the modified Kstiffness method (Miyata and Bathurst, 2007a) as described in Section 3 were also applied to calculate reinforcement loads of the reinforced structures. The tensile stiffness of an individual reinforcement layer $\left(J_{i}\right)$ of the hexagonal wire mesh was obtained from wide width tensile tests and the values were $2170 \mathrm{kN} / \mathrm{m}$ for galvanised-coated wire mesh and $1140 \mathrm{kN} / \mathrm{m}$ for PVC-coated wire (Voottipruex, 2000). The welded wire mats were considered to be elastic material with Young's modulus $(E)$ of $2.0 \times 10^{8} \mathrm{kPa}$ (Bergado et al., 1995) and the cross-sectional area of longitudinal elements per metre width $(A)$ was $180 \mathrm{~mm}^{2}$. As a result, the tensile stiffness of this reinforcement $(E I)$ for this case would be $36000 \mathrm{kN} / \mathrm{m}$. The engineering properties of backfill materials including the unit weight of soil, effective friction angle and cohesion are shown in Table 1.

The coefficient of lateral earth pressure applied in these approaches is a function of the friction angle of the soil. To consider the decrease of lateral earth pressure due to soil cohesion, the plane strain friction angle was calculated from triaxial tests or obtained from a direct shear test as suggested by 


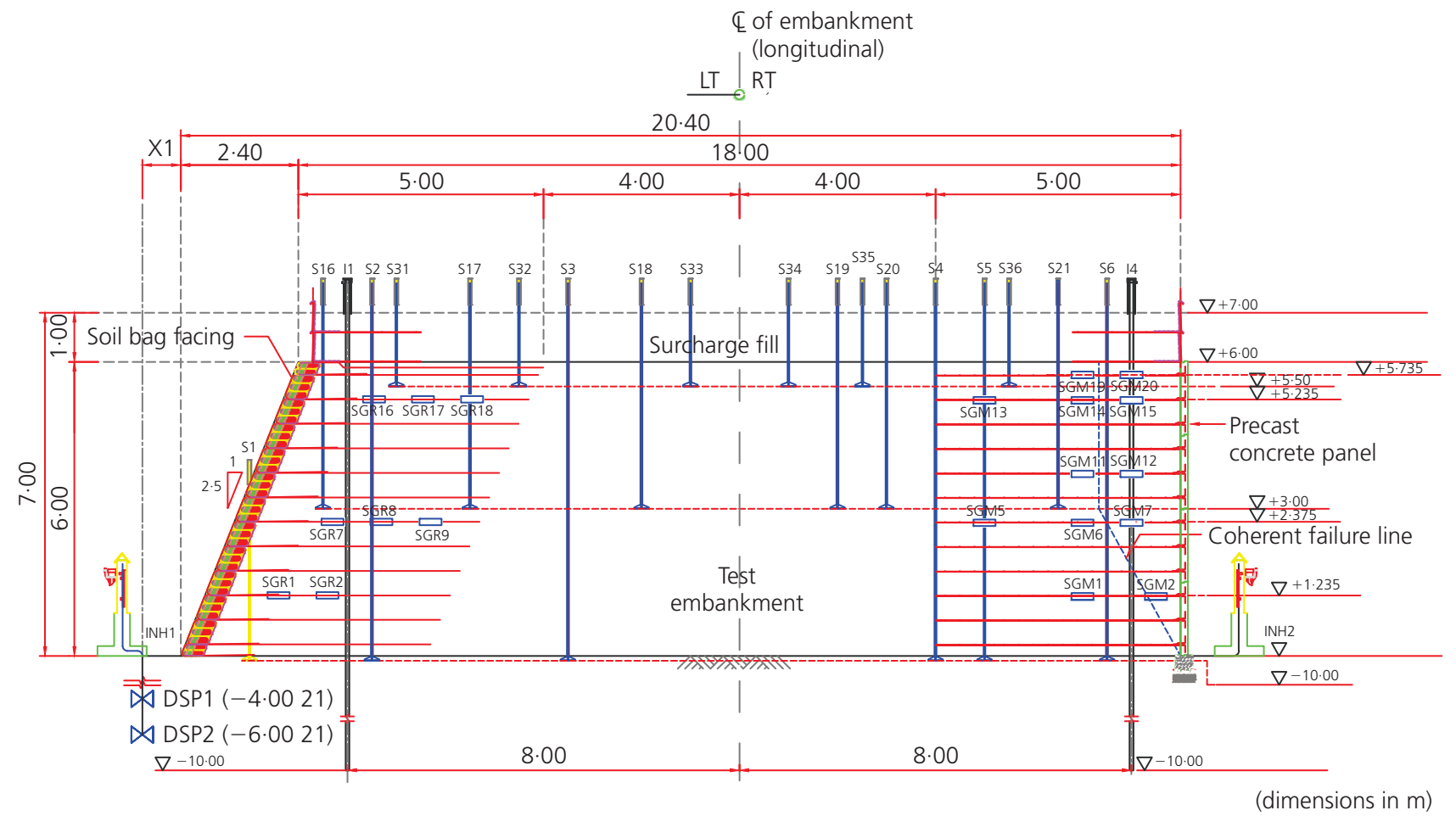

Figure 7. Cross-section of MSE wall/embankment indicating the location of the monitoring instrument. MSE, mechanically stabilised earth
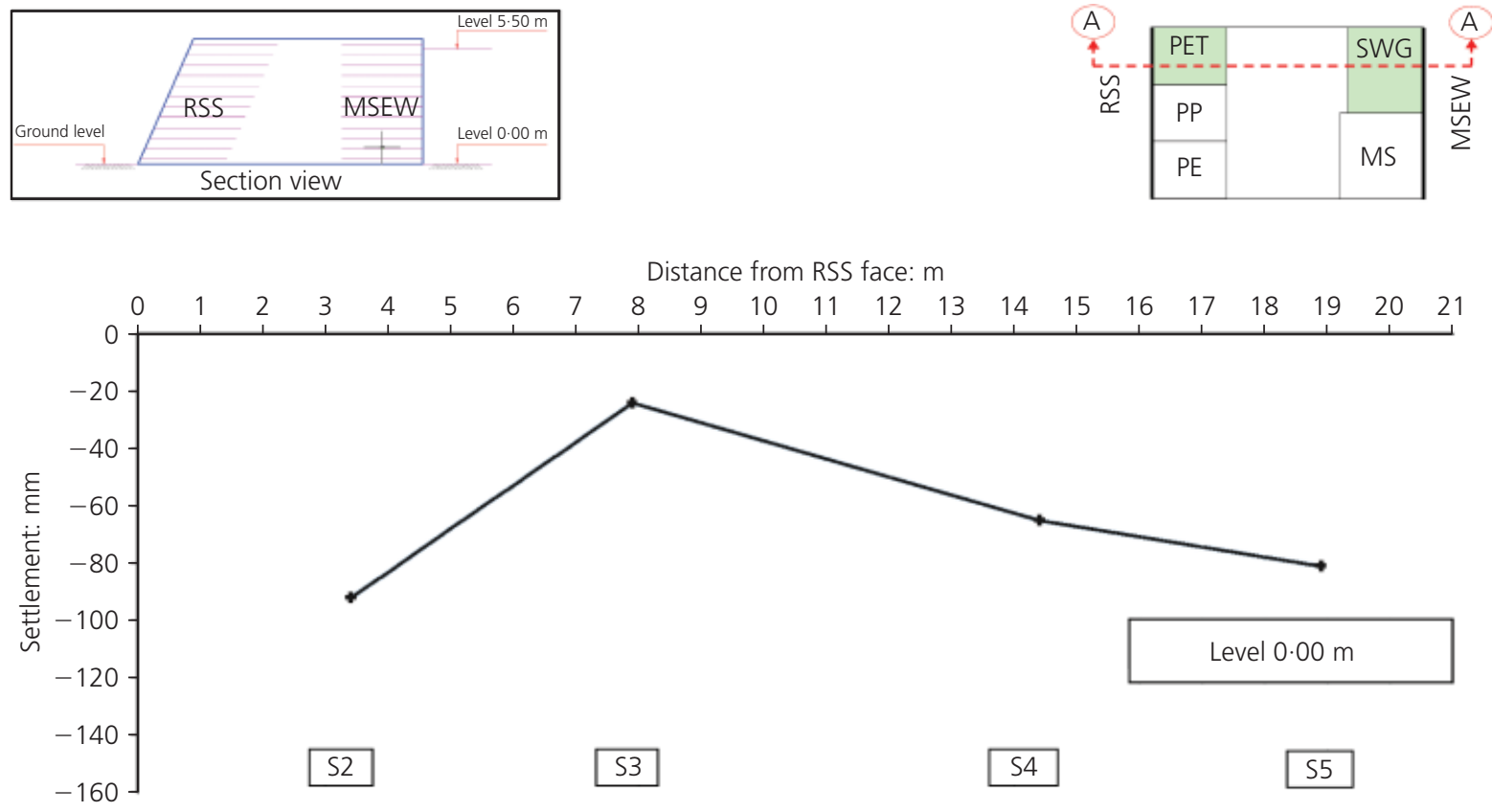

Figure 8. Compression profile of PET-SWG section at level $0.00 \mathrm{~m}$ (bottom of embankment) at 186 days after construction.

MS, metallic strip, MSE, mechanically stabilised earth;

PE, polyethylene; PP, polypropylene; $\mathrm{PET}$, polyester;

RSS, reinforced soil slope; SWG, steel wire grid 


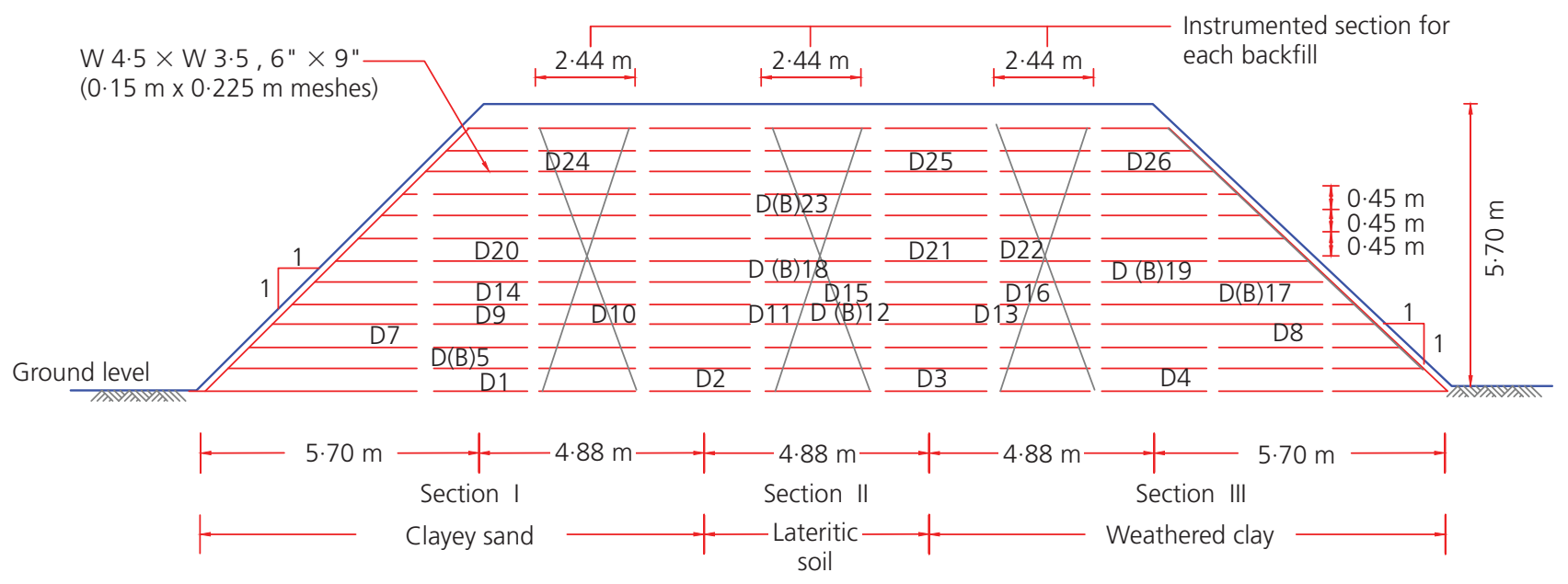

Figure 9. Front (longitudinal) section of the welded wire wall (Bergado et al., 1991a, 1991b)

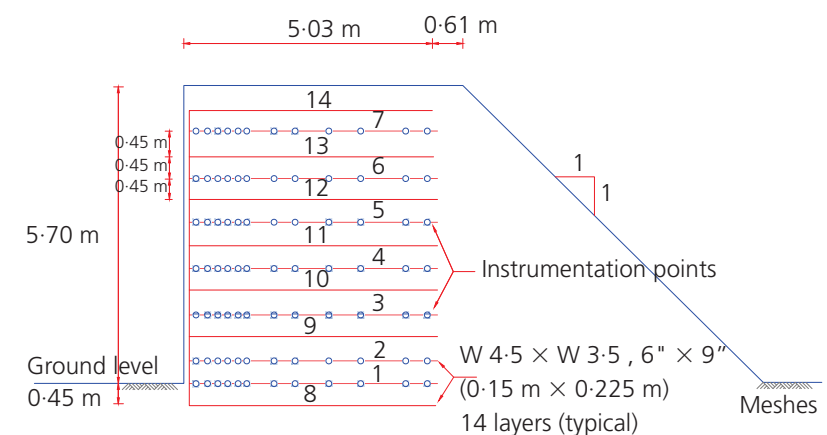

Note: mat nos. 1 to 7 are instrumented mat nos. 8 to 14 are instrumented

Figure 10. View of the welded wire wall along section A-A (Bergado et al., 1991a, 1991b). Note: mats 1 to 7 are instrumented; mats 8 to 14 are not instrumented.
Miyata and Bathurst (2007a), which was used in the AASHTO simplified method and K-stiffness method. The lateral earth pressure coefficient, $K_{\mathrm{a}}$, which is used to calculate the reinforcement loading, was determined using the effective plane strain friction angle $\left(\phi_{\mathrm{ps}}^{\prime}\right)$ of the soil. In general, the reinforcement load increases linearly with depth. The results calculated by this method are dependent on the properties of the backfill soil and indirectly on the properties of the reinforcement through the associated coefficient of earth pressures. However, for the hexagonal grid reinforcement, active earth pressure, $K_{\mathrm{a}}$, can be used (Bergado et al., 2000). Thus, these results are only different for the three kinds of backfill soil with steel grid-reinforced embankment but similar for the two kinds of reinforcement in the case of hexagonal wire-reinforced embankment with silty sand backfill. In the case of the steel grid reinforcement, the reinforcement loads at the base of the wall were about $15,14.5$ and $9 \mathrm{kN} / \mathrm{m}$ for

\begin{tabular}{|c|c|c|c|c|}
\hline & \multicolumn{3}{|c|}{$\begin{array}{l}\text { Shivashankar (1991), } \\
\text { Bergado et al. (1991a, 1991b) }\end{array}$} & \multirow{2}{*}{$\begin{array}{l}\text { Voottipruex (2000), } \\
\text { Bergado et al. (2000) } \\
\text { Reinforcement type }\end{array}$} \\
\hline & \multicolumn{3}{|c|}{ Fill material type } & \\
\hline & Clayey sand & Lateritic soil & Weathered clay & PVC-coated wire mesh \\
\hline Peak triaxial friction angle, $\phi_{\mathrm{tx}}^{\prime}:^{\circ}$ & 24 & $25 \cdot 2$ & 24 & 30 \\
\hline Cohesion, $c^{\prime}: \mathrm{kN} / \mathrm{m}^{2}$ & 10 & 20 & 30 & 5 \\
\hline Unit weight of the soil, $\gamma: \mathrm{kN} / \mathrm{m}^{3}$ & 17 & $19 \cdot 3$ & $16 \cdot 3$ & 18 \\
\hline Height of the wall, $H: m$ & $5 \cdot 7$ & $5 \cdot 7$ & $5 \cdot 7$ & 6 \\
\hline $\begin{array}{l}\text { Equivalent height of uniform surcharge } \\
\text { pressure, } S \text { : } m\end{array}$ & 0 & 0 & 0 & 0 \\
\hline Tributary area, $S_{v}: m$ & 0.45 & 0.45 & 0.45 & 0.5 \\
\hline Tensile stiffness, $J_{\mathrm{i}}=J_{2} \%: \mathrm{kN} / \mathrm{m}$ & 36000 & 36000 & 36000 & 1140 \\
\hline
\end{tabular}




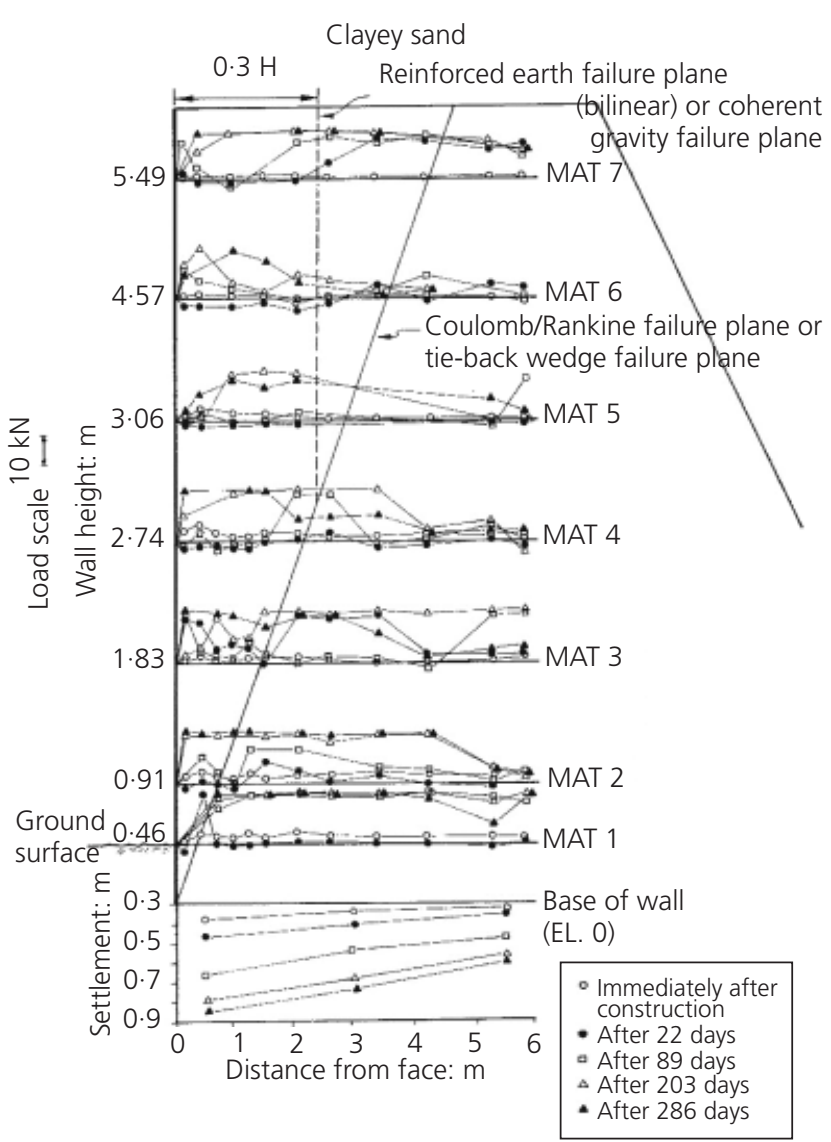

Figure 11. Variation of tensions in the longitudinal bars immediately after construction and for different periods after construction (clayey sand) (Bergado et al., 1991a, 1991b)
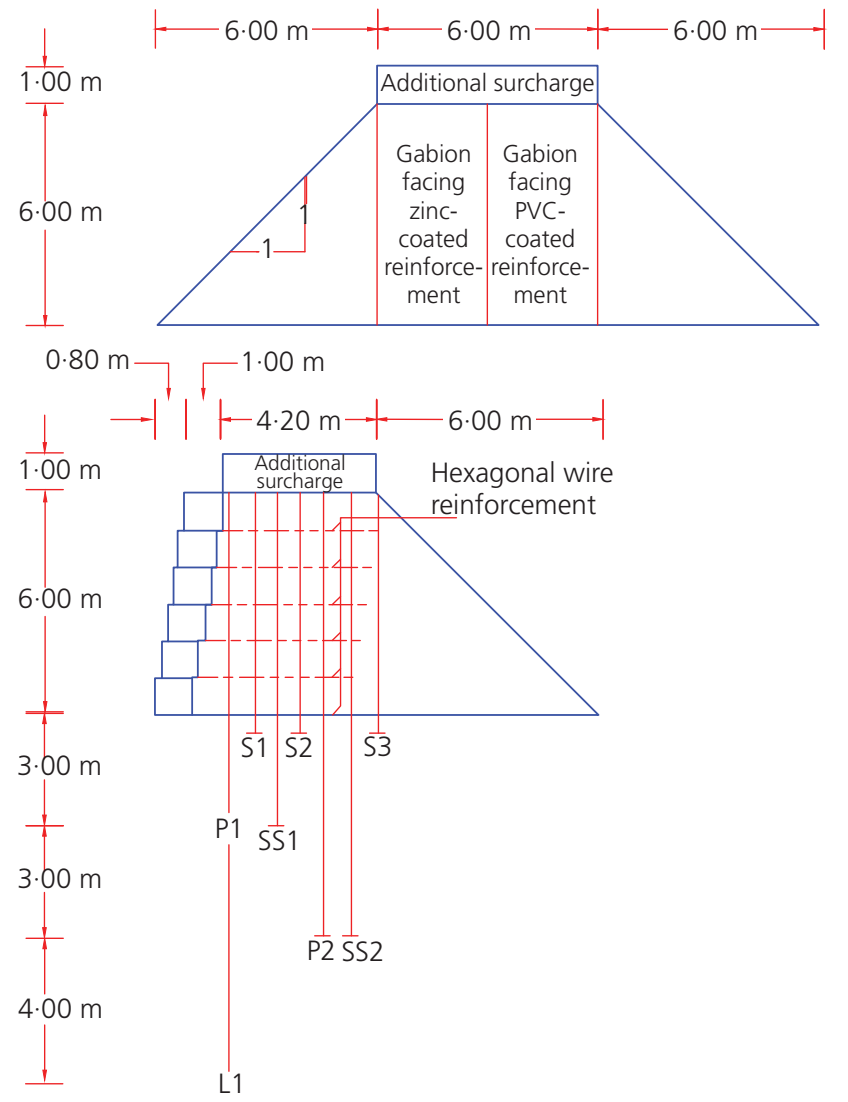

Figure 13. Front and section and views of the hexagonal wire-reinforced wall (Voottipruex, 2000)

were similar. For the steel grid-reinforced embankment, the presence of soil cohesion resulted in the maximum values of reinforcement loads for the clayey sand, followed by that of lateritic soil and weathered clay backfills.

\section{Presentation of measured reinforcement loads and strain values}

The reinforcement strains recorded in the field were deduced from strain gauges directly attached to the reinforcements within the embankment. The maximum measured reinforcement loads and strains for every reinforcement layer immediately after construction and at different durations after construction are tabulated in Tables 2 and 3, respectively. Furthermore, the recorded ground settlements were also observed for embankments on soft and hard ground foundations immediately after construction and at different durations after construction as shown in Table 4.

\subsection{Hard ground foundation}

The information gathered from two reinforced embankments constructed on hard ground foundation were utilised in order 


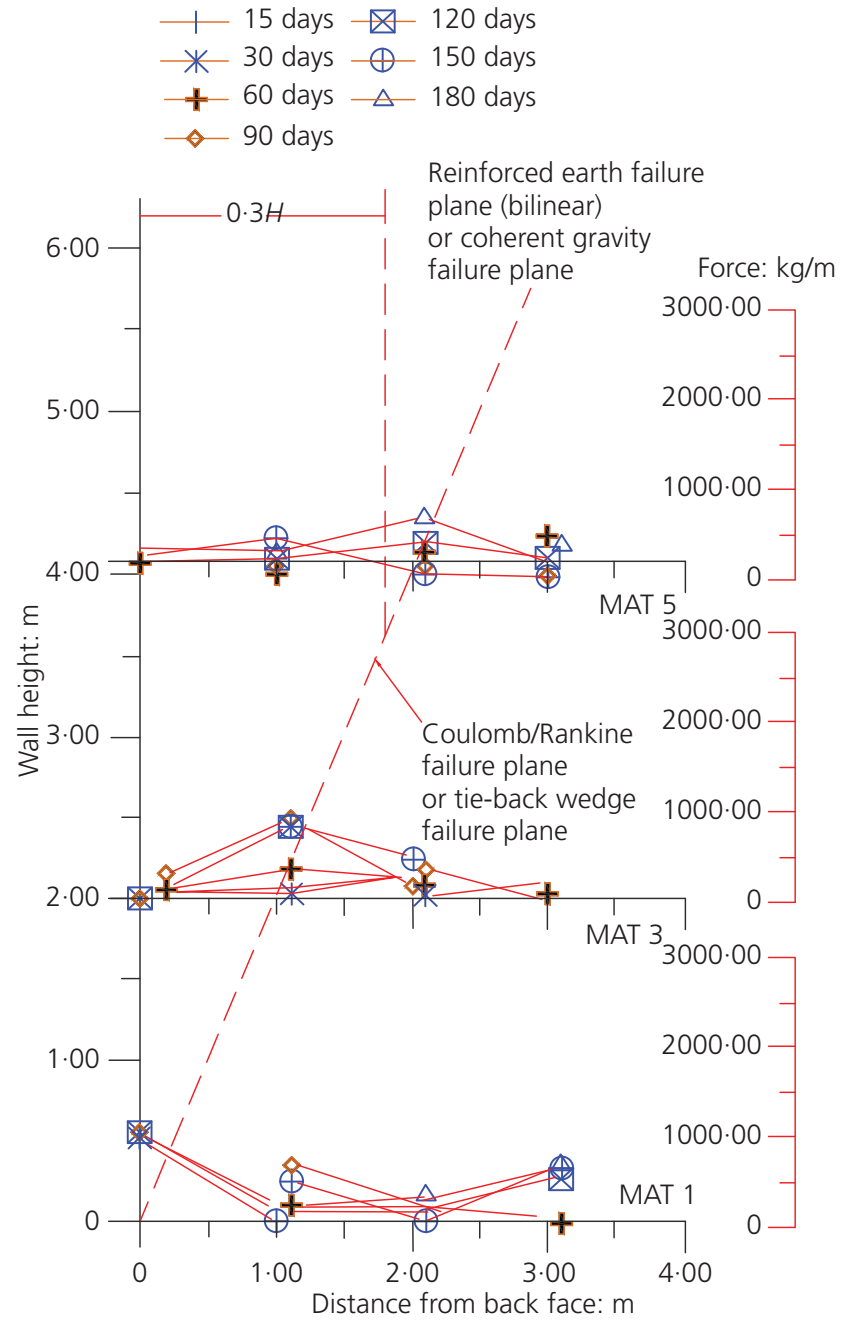

Figure 14. Reinforcement tension of PVC-coated wire mesh at different periods after construction (Voottipruex, 2000)

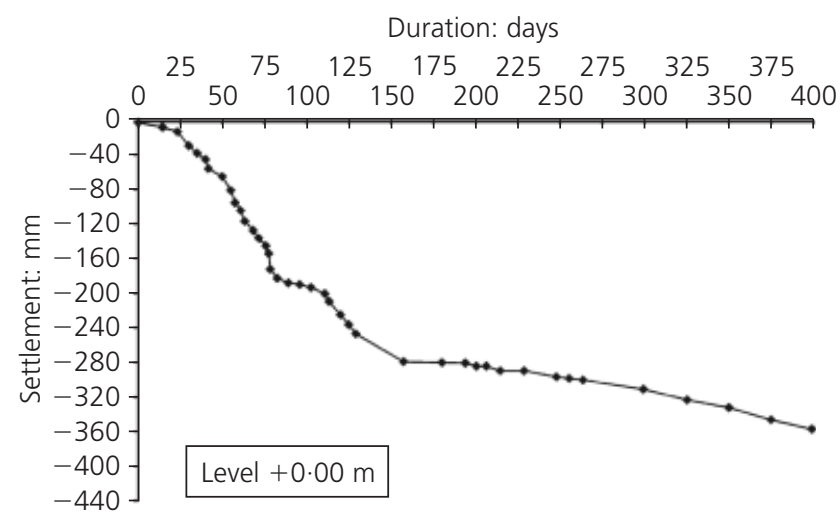

Figure 15. Observed ground surface settlement for embankment reinforced with PVC-coated wire mesh (Voottipruex, 2000) to study the behaviour of reinforcement load within the embankment. The test embankment was constructed using a 50:50 by volume mixture of lateritic soil and sand as backfill material with effective cohesion of $10 \mathrm{kPa}$ and effective friction angle of $32.8^{\circ}$ and reinforced with polymer geogrids (PET, PP and HDPE) and metallic (SWG and MS) reinforcements (Nualkliang, 2011). Generally, the magnitudes of observed reinforcement strains and loads increased with time, ground settlements and depths from the top of the embankment.

The loads and strains in the reinforcements at maximum tension line for geogrids (PET, PP and HDPE) as well as metallic (steel wire grids and metallic strips) in reinforced embankment constructed on hard foundation were recorded at 125 and 186 days corresponding to 0 and 61 days after the final application of surcharge load, respectively, are presented in Tables 2 and 3. Figure 16(a) and (b) compare the predicted and measured loads for geogrids and metallic-reinforced sections, respectively, of the embankment. For the PET geogridreinforced section of the embankment, the maximum observed strain value was about $0.735 \%$, which is equivalent to $6.61 \mathrm{kN} / \mathrm{m}$ of reinforcement load and was observed at 125 days. At 186 days, the strain increased to $0 \cdot 810 \%$, which is approximately equal to $7.29 \mathrm{kN} / \mathrm{m}$ of reinforcement load. The behaviour of strain values of PP and HDPE geogrids were almost similar as the values of their tensile stiffness were relatively close at 1500 and $1275 \mathrm{kN} / \mathrm{m}$, respectively. The maximum strain and reinforcement load values were obtained at the bottom instrumented reinforcement layer. The observed settlements at the ground surface are tabulated in Table 4. For PET geogrid section of the reinforced embankment, the measured settlements were 48 and $59 \mathrm{~mm}$ at 125 and 186 days, respectively. The PP geogrid-reinforced portion settled by about 40 and $52 \mathrm{~mm}$ at 125 and 186 days, respectively. After 125 and 186 days, the observed ground settlements for the HDPEreinforced section of the embankment were only 34 and $44 \mathrm{~mm}$, respectively.

For the other side of this embankment on hard foundation where metallic (steel wire grids and metallic strips) reinforcements were used, the maximum recorded strains for steel wire grid section were 0.012 and $0.016 \%$ at 125 and 186 days, respectively, as tabulated in Table 3 . These strain values were converted to load with magnitudes of 4.10 and $5.52 \mathrm{kN} / \mathrm{m}$. The section reinforced with metallic strips reached maximum reinforcement strain values of 0.008 and $0.011 \%$ at 125 and 186 days, respectively, as presented in Table 3 with corresponding values of reinforcement loads of $7 \cdot 18$ and $9.70 \mathrm{kN} / \mathrm{m}$. At 125 days, both sections of the metallic-reinforced embankment settled by about $52 \mathrm{~mm}$. The recorded differential ground settlements slightly changed at 186 days by approximately $8 \mathrm{~mm}$ where the section reinforced with steel wire grid settled at about $68 \mathrm{~mm}$ whereas the metallic strip section moved vertically by about $60 \mathrm{~mm}$ as shown in Table 4 . 


\begin{tabular}{|c|c|c|c|c|c|c|c|c|c|c|c|c|c|c|c|}
\hline \multirow[t]{3}{*}{ Reinforced wall } & \multirow{3}{*}{$\begin{array}{c}\text { Duration: } \\
\text { days }\end{array}$} & \multicolumn{13}{|c|}{$T_{\max }: \mathrm{kN} / \mathrm{m}$} & \multirow{3}{*}{$\begin{array}{l}\text { No. o } \\
\text { layers }\end{array}$} \\
\hline & & \multicolumn{13}{|c|}{ Layer number (1 as the top most reinforcement layer of the embankment) } & \\
\hline & & 1 & 2 & 3 & 4 & 5 & 6 & 7 & 8 & 9 & 10 & 11 & 12 & 13 & \\
\hline \multicolumn{16}{|l|}{ Hard foundation } \\
\hline \multirow[t]{4}{*}{ HWG (Lai, 2009) } & 0 & & $1 \cdot 105$ & & $2 \cdot 085$ & & $2 \cdot 899$ & & $5 \cdot 183$ & & & & & & 8 \\
\hline & 10 & & $2 \cdot 134$ & & $3 \cdot 266$ & & $3 \cdot 898$ & & $7 \cdot 949$ & & & & & & \\
\hline & 120 & & $2 \cdot 343$ & & $4 \cdot 577$ & & $4 \cdot 668$ & & $10 \cdot 471$ & & & & & & \\
\hline & 210 & & $2 \cdot 705$ & & $4 \cdot 740$ & & $6 \cdot 412$ & & $10 \cdot 593$ & & & & & & \\
\hline \multirow[t]{2}{*}{ PET (Duangkhae, 2013) } & 125 & & & 0.685 & & & & & $4 \cdot 646$ & & & $6 \cdot 612$ & & & 13 \\
\hline & 186 & & & 1.793 & & & & & $5 \cdot 198$ & & & $7 \cdot 293$ & & & \\
\hline \multirow[t]{2}{*}{ PP (Duangkhae, 2013) } & 125 & & & 0.417 & & & & & $4 \cdot 592$ & & & $7 \cdot 355$ & & & 13 \\
\hline & 186 & & & 0.962 & & & & & $5 \cdot 042$ & & & $7 \cdot 748$ & & & \\
\hline \multirow[t]{2}{*}{ HDPE (Duangkhae, 2013) } & 125 & & & 1.015 & & & & & $5 \cdot 104$ & & & $6 \cdot 616$ & & & 13 \\
\hline & 186 & & & $1 \cdot 156$ & & & & & $5 \cdot 102$ & & & $6 \cdot 628$ & & & \\
\hline SWG (Duangkhae, 2013) & 125 & & $1 \cdot 617$ & 1.649 & & & 1.635 & & $4 \cdot 097$ & & & $3 \cdot 121$ & & & 13 \\
\hline \multirow[t]{2}{*}{ MS (Duangkhae, 2013) } & 125 & & & $2 \cdot 163$ & & & & & $7 \cdot 180$ & & & $7 \cdot 140$ & & & 13 \\
\hline & 186 & & & $2 \cdot 689$ & & & & & 8.009 & & & $9 \cdot 701$ & & & \\
\hline \multicolumn{16}{|l|}{ Soft foundation } \\
\hline \multirow[t]{3}{*}{ SWG-CS (Shivashankar, 1991) } & 0 & & 1.695 & & $1 \cdot 864$ & & 4.915 & & $6 \cdot 186$ & & $4 \cdot 805$ & & $4 \cdot 831$ & $4 \cdot 559$ & 13 \\
\hline & 89 & & $10 \cdot 025$ & & 7.897 & & $14 \cdot 115$ & & $16 \cdot 691$ & & $17 \cdot 020$ & & $14 \cdot 343$ & $15 \cdot 582$ & \\
\hline & 203 & & $10 \cdot 120$ & & $8 \cdot 276$ & & $15 \cdot 648$ & & $18 \cdot 782$ & & $18 \cdot 654$ & & $17 \cdot 889$ & $17 \cdot 889$ & \\
\hline \multirow[t]{3}{*}{ SWG-LS (Shivashankar, 1991) } & 0 & & $1 \cdot 728$ & & $4 \cdot 444$ & & 4.033 & & 4.457 & & $4 \cdot 140$ & & $5 \cdot 267$ & $6 \cdot 173$ & 13 \\
\hline & 89 & & 5.679 & & $10 \cdot 635$ & & $15 \cdot 219$ & & $15 \cdot 039$ & & $15 \cdot 871$ & & $16 \cdot 844$ & $15 \cdot 595$ & \\
\hline & 203 & & 14.575 & & 11.042 & & $16 \cdot 945$ & & $16 \cdot 392$ & & $16 \cdot 445$ & & $19 \cdot 969$ & $17 \cdot 179$ & \\
\hline \multirow[t]{3}{*}{ SWG-WC (Shivashankar, 1991) } & 0 & & $2 \cdot 760$ & & $3 \cdot 673$ & & $5 \cdot 224$ & & $7 \cdot 235$ & & 6.939 & & $4 \cdot 245$ & $8 \cdot 816$ & 13 \\
\hline & 89 & & 8.332 & & $15 \cdot 912$ & & 14.659 & & $15 \cdot 595$ & & $17 \cdot 540$ & & $16 \cdot 836$ & 14.444 & \\
\hline & 203 & & $10 \cdot 134$ & & $15 \cdot 826$ & & $16 \cdot 061$ & & $17 \cdot 996$ & & $18 \cdot 190$ & & $17 \cdot 935$ & $18 \cdot 225$ & \\
\hline \multirow[t]{3}{*}{ HWG-PVC (Voottipruex, 2000) } & 15 & & & & 1.044 & & & & $1 \cdot 822$ & & & & $4 \cdot 288$ & & 12 \\
\hline & 120 & & & & $3 \cdot 279$ & & & & $7 \cdot 793$ & & & & $7 \cdot 884$ & & \\
\hline & 180 & & & & $5 \cdot 365$ & & & & $8 \cdot 017$ & & & & 8.055 & & \\
\hline
\end{tabular}

CS, clayey sand; HDPE, high-density polyethylene; HWG, hexagonal wire-reinforced grid; LS, lateritic soil; MS, metallic strip; PET, polyester; PP, polypropylene; SWG, steel wire grid; WC, weathered clay

Table 2. Tabulation of maximum measured reinforcement loads for each reinforcement layer $\left(T_{\max }\right)$ 


\begin{tabular}{|c|c|c|c|c|c|c|c|c|c|c|c|c|c|c|c|}
\hline \multirow[t]{3}{*}{ Reinforced wall } & \multirow{3}{*}{$\begin{array}{c}\text { Duration: } \\
\text { days }\end{array}$} & \multicolumn{13}{|c|}{ Strain: \% } & \multirow{3}{*}{$\begin{array}{l}\text { No. of } \\
\text { layers }\end{array}$} \\
\hline & & \multicolumn{13}{|c|}{ Layer number ( 1 as the top most reinforcement layer of the embankment) } & \\
\hline & & 1 & 2 & 3 & 4 & 5 & 6 & 7 & 8 & 9 & 10 & 11 & 12 & 13 & \\
\hline \multicolumn{16}{|l|}{ Hard foundation } \\
\hline \multirow[t]{3}{*}{ HWG (Lai, 2009) } & 0 & & 0.232 & & 0.437 & & 0.608 & & 1.087 & & & & & & 8 \\
\hline & 10 & & $0 \cdot 447$ & & 0.685 & & 0.817 & & 1.666 & & & & & & \\
\hline & 210 & & 0.567 & & 0.994 & & $1 \cdot 344$ & & $2 \cdot 221$ & & & & & & \\
\hline \multirow[t]{2}{*}{ PET (Duangkhae, 2013) } & 125 & & & 0.076 & & & & & 0.516 & & & 0.735 & & & 13 \\
\hline & 186 & & & $0 \cdot 199$ & & & & & 0.578 & & & 0.810 & & & \\
\hline \multirow[t]{2}{*}{ PP (Duangkhae, 2013) } & 125 & & & 0.028 & & & & & $0 \cdot 306$ & & & 0.490 & & & 13 \\
\hline & 186 & & & 0.064 & & & & & 0.336 & & & 0.517 & & & \\
\hline \multirow[t]{2}{*}{ HDPE (Duangkhae, 2013) } & 125 & & & 0.080 & & & & & 0.400 & & & $0 \cdot 519$ & & & 13 \\
\hline & 186 & & & 0.091 & & & & & 0.400 & & & 0.520 & & & \\
\hline SWG (Duangkhae, 2013) & 125 & & 0.005 & 0.005 & & & 0.005 & & 0.012 & & & 0.009 & & & 13 \\
\hline \multirow[t]{2}{*}{ MS (Duangkhae, 2013) } & 125 & & & 0.002 & & & & & 0.008 & & & 0.008 & & & 13 \\
\hline & 186 & & & 0.003 & & & & & 0.009 & & & 0.011 & & & \\
\hline \multicolumn{16}{|l|}{ Soft foundation } \\
\hline \multirow{3}{*}{ SWG-CS (Shivashankar, 1991) } & 0 & & 0.005 & & 0.005 & & 0.014 & & 0.017 & & 0.013 & & 0.013 & 0.013 & 13 \\
\hline & 89 & & 0.028 & & 0.022 & & 0.039 & & 0.046 & & 0.047 & & 0.040 & 0.043 & \\
\hline & 203 & & 0.028 & & 0.023 & & 0.043 & & 0.052 & & 0.052 & & 0.050 & 0.050 & \\
\hline \multirow[t]{3}{*}{ SWG-LS (Shivashankar, 1991) } & 0 & & 0.005 & & 0.012 & & 0.011 & & 0.012 & & 0.011 & & 0.015 & 0.017 & 13 \\
\hline & 89 & & 0.016 & & 0.030 & & 0.042 & & 0.042 & & 0.044 & & 0.047 & 0.043 & \\
\hline & 203 & & 0.040 & & 0.031 & & 0.047 & & 0.046 & & 0.046 & & 0.055 & 0.048 & \\
\hline \multirow[t]{3}{*}{ SWG-WC (Shivashankar, 1991) } & 0 & & 0.008 & & 0.010 & & 0.015 & & 0.020 & & 0.019 & & 0.012 & 0.024 & 13 \\
\hline & 89 & & 0.023 & & 0.044 & & 0.041 & & 0.043 & & 0.049 & & 0.047 & 0.040 & \\
\hline & 203 & & 0.028 & & 0.044 & & 0.045 & & 0.050 & & 0.051 & & 0.050 & 0.051 & \\
\hline \multirow[t]{3}{*}{ HWG-PVC (Voottipruex, 2000) } & 15 & & & & 0.092 & & & & $0 \cdot 160$ & & & & 0.376 & & 12 \\
\hline & 120 & & & & 0.288 & & & & 0.684 & & & & 0.692 & & \\
\hline & 180 & & & & 0.471 & & & & 0.703 & & & & 0.707 & & \\
\hline
\end{tabular}

CS, clayey sand; HDPE, high-density polyethylene; HWG, hexagonal wire-reinforced grid; LS, lateritic soil; MS, metallic strip; PET, polyester; PP, polypropylene; SWG, steel wire grid; WC, weathered clay

Table 3. Tabulation of maximum measured reinforcement strains for each reinforcement layer (\%) 


\begin{tabular}{|c|c|c|c|c|c|c|c|c|c|c|}
\hline \multirow{5}{*}{$\begin{array}{l}\text { Duration after } \\
\text { construction: } \\
\text { days }\end{array}$} & \multicolumn{10}{|c|}{ Settlement: mm } \\
\hline & \multicolumn{6}{|c|}{ Hard foundation } & \multicolumn{4}{|c|}{ Soft foundation } \\
\hline & \multirow[t]{3}{*}{ Hexagonal wire grid } & \multicolumn{5}{|c|}{ Reinforcement type } & \multicolumn{2}{|c|}{ Backfill material type } & \multicolumn{2}{|c|}{ Reinforcement type (wire mesh } \\
\hline & & \multicolumn{3}{|c|}{ Geogrid } & \multicolumn{2}{|c|}{ Metallic } & \multirow[t]{2}{*}{ Clayey sand } & \multirow[t]{2}{*}{ Lateritic soil } & \multirow{2}{*}{$\begin{array}{l}\text { Weathered } \\
\text { clay }\end{array}$} & \multirow[t]{2}{*}{ PVC coated } \\
\hline & & PET & PP & HDPE & SWG & MS & & & & \\
\hline 0 & 99.63 & & & & & & $344 \cdot 53$ & $507 \cdot 28$ & $375 \cdot 62$ & \\
\hline 10 & $144 \cdot 44$ & & & & & & & & & \\
\hline 15 & & & & & & & & & & $144 \cdot 70$ \\
\hline 89 & & & & & & & $541 \cdot 70$ & $824 \cdot 52$ & $603 \cdot 48$ & \\
\hline \multicolumn{11}{|l|}{115} \\
\hline 120 & 263.09 & & & & & & & & & $279 \cdot 70$ \\
\hline 180 & & & & & & & & & & $296 \cdot 28$ \\
\hline $186(61)^{*}$ & & $59 \cdot 00$ & $51 \cdot 67$ & 44.00 & $68 \cdot 33$ & $60 \cdot 67$ & & & & \\
\hline 203 & & & & & & & $680 \cdot 90$ & 948.63 & $713 \cdot 30$ & \\
\hline 210 & $296 \cdot 11$ & & & & & & & & & \\
\hline 245 & & & & & & & & & & \\
\hline
\end{tabular}

* ( ) number of days after application of surcharge load. HDPE, high-density polyethylene; MS, metallic strip; PET, polyester; PP, polypropylene; SWG, steel wire grid

Table 4. Tabulation of ground settlements for wall case histories immediately after construction and at different durations after construction. 


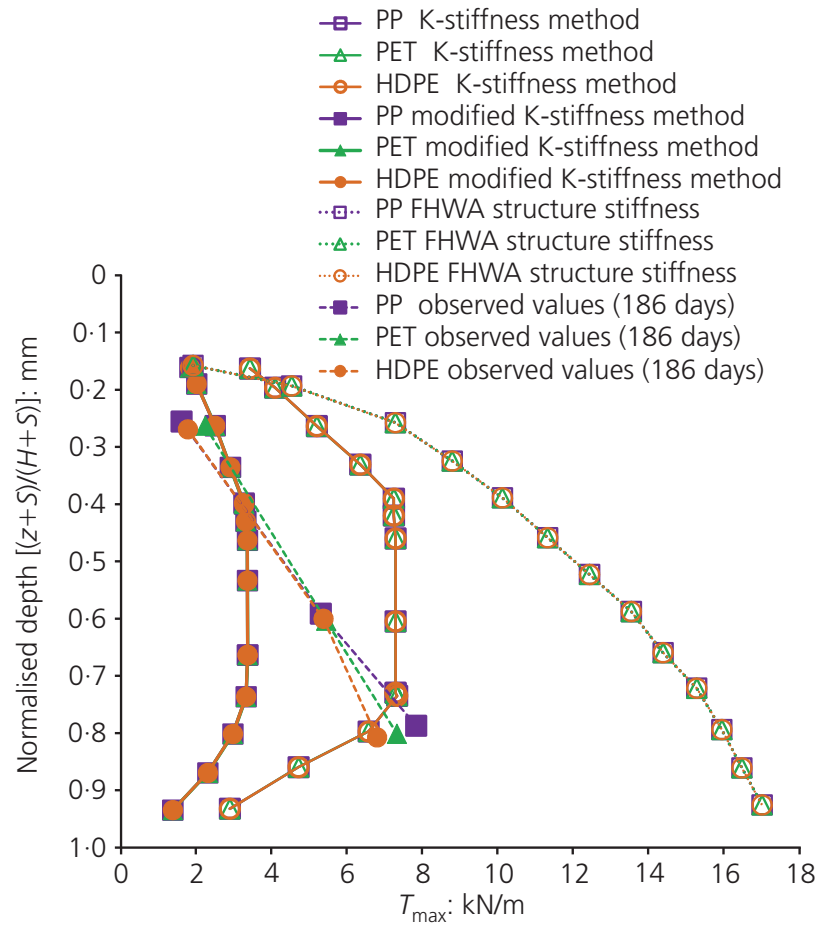

(a)

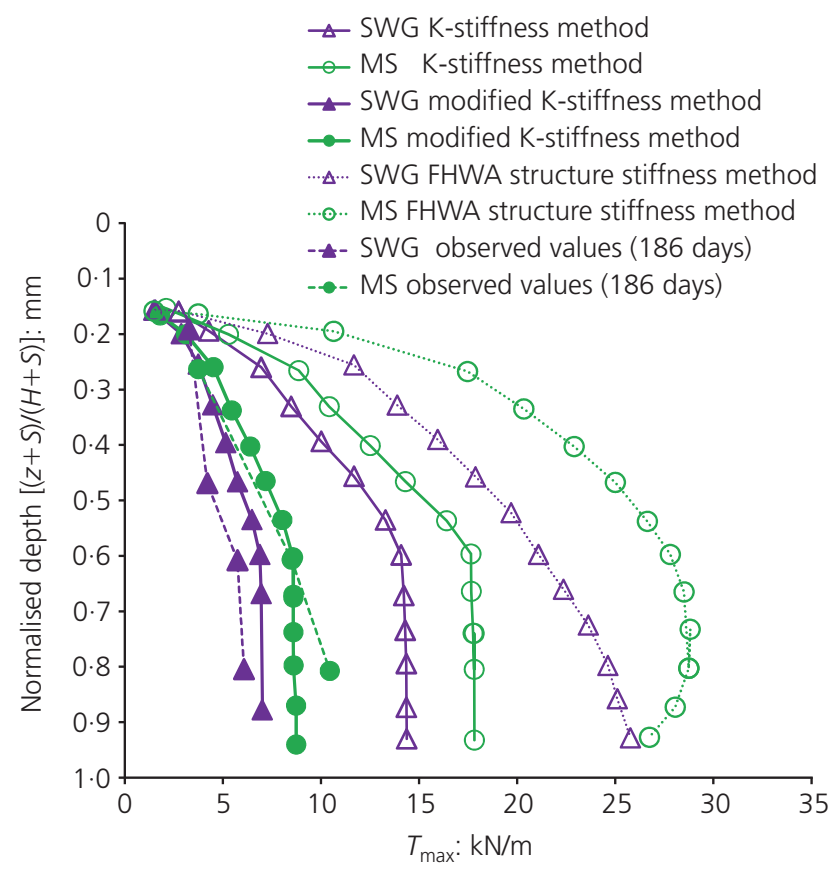

(b)

Figure 16. Measured and predicted. $T_{\max }$ plotted against normalised depth for polymeric and metallic reinforcements using modified K-stiffness method compared with measured values.

(a) $T_{\max }$ plotted against normalised depth for polymeric reinforcement; (b) $T_{\max }$ plotted against normalised depth for metallic reinforcement. FHWA, Federal Highway Administration; HDPE, high-density polyethylene; MS, metallic strip; PET, polyester; PP, polypropylene; SWG; steel wire grid

\subsection{Soft ground foundation}

In the first steel grid-reinforced embankment the measured reinforcement loads and strains respectively, are shown in Tables 2 and 3 for the reinforced section of the embankment backfilled with clayey sand. Moreover, the settlement values are presented in Table 4. As presented in Table 2, the maximum measured reinforcement loads in the embankment recorded for clayey sand section were $6 \cdot 19,17.02$ and $18 \cdot 78 \mathrm{kN} / \mathrm{m}$ for the duration of 0,89 and 203 days after construction, respectively. The equivalent strain readings of these loads were $0.017,0.047$ and $0.052 \%$. From the time immediately after construction up to 203 days, the observed maximum reinforcement load increased to three times its initial value due to considerable settlements of the soft ground foundation during these periods. The embankment settled by about 345,542 and $681 \mathrm{~mm}$, respectively, at durations of 0,89 and 203 days after construction as shown in Table 4. For the reinforced section of the embankment backfilled with lateritic soil, the measured reinforcement loads and strains are shown in Tables 2 and 3, respectively. Moreover, the settlement values are presented in Table 4. A significant increase in reinforcement loads was noticed immediately after construction up to 89 days after completion of the embankment. At this stage, the ground settled considerably. After 89 days, the change in reinforcement loads was minimal. In general, the majority of the measured maximum reinforcement loads in the steel grid-reinforced embankment at different durations were observed near the bottom of the embankment due to the concave shape of the settlement pattern of the soft ground foundation.

For the second embankment that was reinforced with two types of hexagonal wire mesh reinforcement (zinc-coated and PVCcoated) and backfilled with silty sand, the measured reinforcement loads and strains are shown in Tables 2 and 3, respectively. Moreover, the settlement values are presented in Table 4. From 120 to 180 days after construction, the increase in maximum reinforcement load was just minimal. The magnitudes of ground settlements at 15, 120 and 180 days after construction were 145, 280 and $296 \mathrm{~mm}$, respectively, as presented in Table 4. Adjacent to this section was a portion of the embankment reinforced with zinc-coated hexagonal wire mesh. Contrary to the reinforcement load behaviour with respect to time for PVC-coated hexagonal wire mesh section, the magnitudes of reinforcement loads in this section showed substantial increase in magnitude from 120 to 180 days after construction although the change in ground settlements during this period was relatively small. Consequently the data obtained in this section were not included in the subsequent analyses.

\section{Comparison of measured and predicted loads and strain values for reinforced embankments on soft foundation}

The observed maximum reinforcement load and strain for every reinforcement layer at different durations after construction are shown in Tables 2 and 3 and plotted against normalised depth as shown in Figures 17 to 20 in order to visually compare with the 


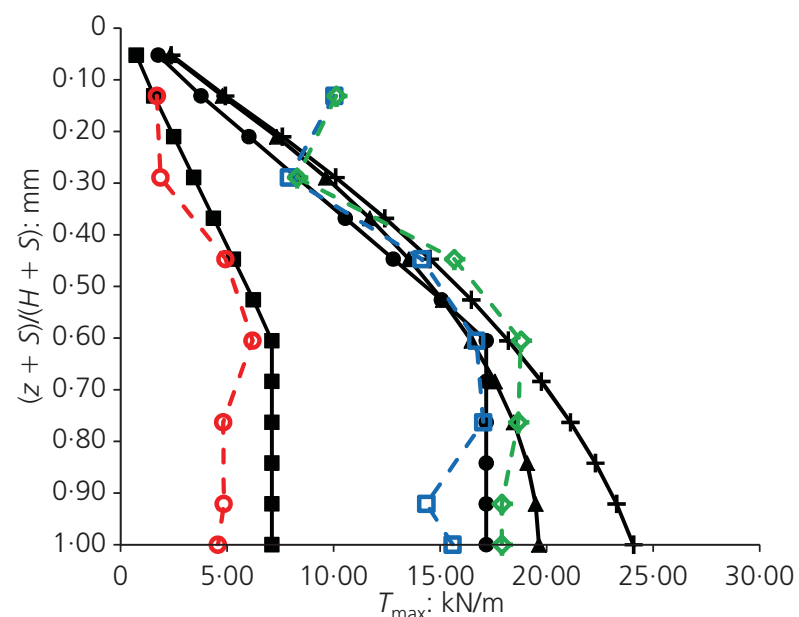

(a)

$\rightarrow$ K-stiffness method $(c=0)$

$\rightarrow-$ Modified K-stiffness method ( $c>0$ )

$\rightarrow$ AASHTO simplified method $(c=0)$

$\rightarrow$ FHWA structure stiffness method $(c=0)$

-o- Observed values (0 days)

-ㅁ- Observed values (89 days)

$-\infty$ Observed values (203 days)

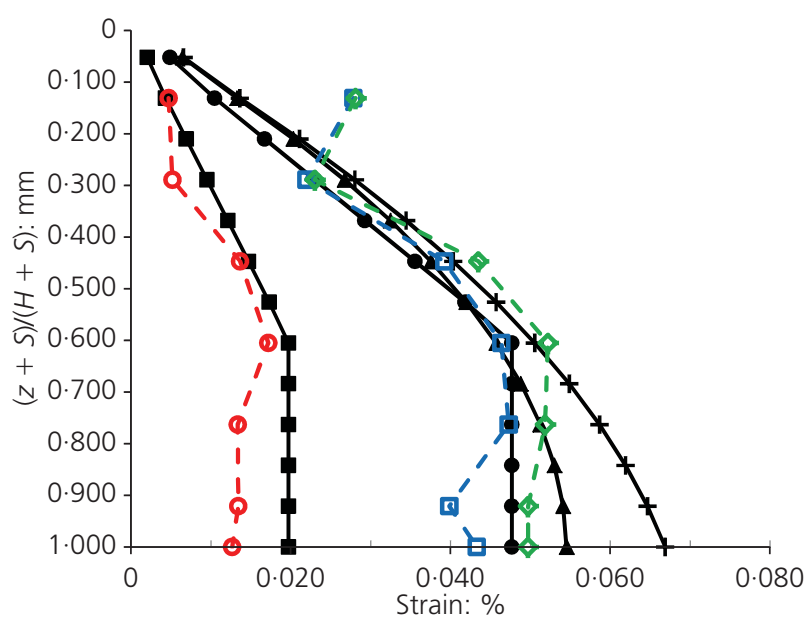

(b)

Figure 17. Measured and predicted reinforcement load and strain for SWG embankment with poor-quality backfills (clayey sand) on soft ground (Shivashankar, 1991). (a) Comparison of measured and predicted reinforcement load; (b) comparison of measured and predicted reinforcement strain. SWG, steel wire grid

distribution and magnitude of reinforcement loads and strains calculated using the prediction methods. The horizontal axis represents the maximum reinforcement load and strain in each reinforcement layer (both measured and predicted values) while the vertical axis demonstrates the ratio of the sum of reinforcement location depth and surcharge height to the sum of the heights of the embankment and surcharge.

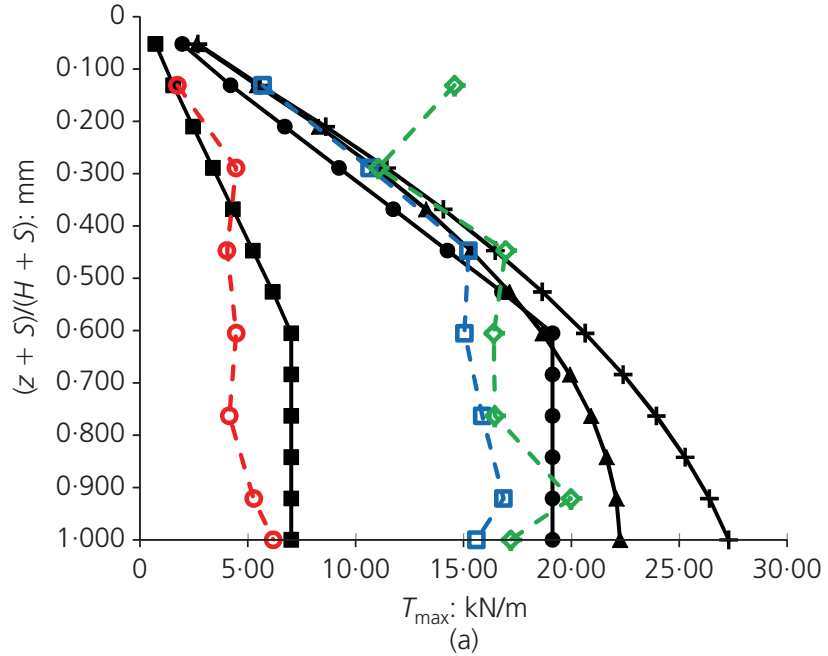

$\rightarrow$ K-stiffness method ( $c=0$ )

$\rightarrow$ Modified K-stiffness method ( $c>0$ )

$\leftarrow$ AASHTO simplified method $(c=0)$

$\longrightarrow$ FHWA structure stiffness method $(c=0)$

-o- Observed values (0 days)

- - Observed values (89 days)

- Observed values (203 days)

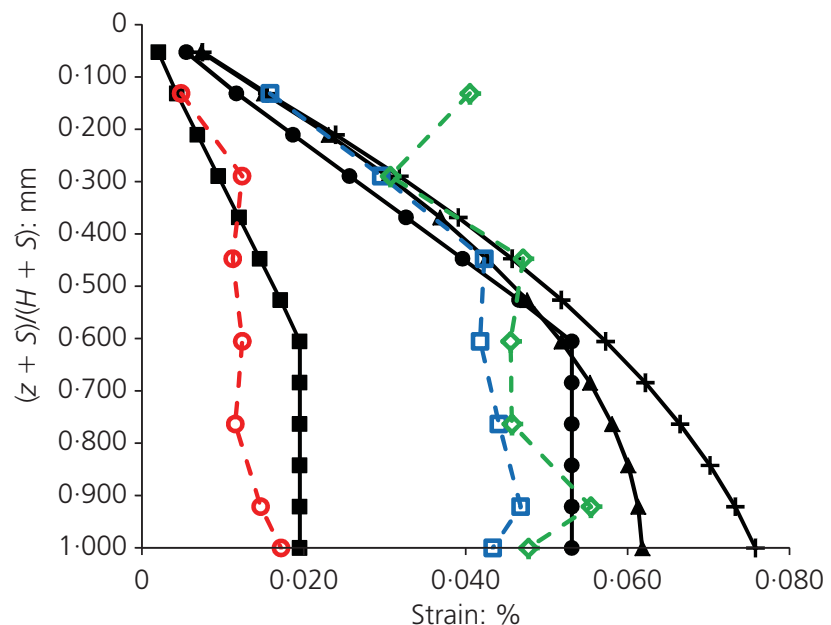

(b)

Figure 18. Measured and predicted reinforcement load and strain for SWG embankment with poor-quality backfills (lateritic residual soil) on soft ground (Shivashankar, 1991).

(a) Comparison of measured and predicted reinforcement load;

(b) comparison of measured and predicted reinforcement strain.

SWG, steel wire grid

\subsection{Immediately after construction}

It is evident in Figures 17 to 20 that immediately after construction of the reinforced embankment, the two limit equilibrium methods investigated in this study predicted the reinforcement loads and strains higher than the measured values. In agreement with the findings of Tin (2009), the magnitudes of reinforcement load predicted using the FHWA structure stiffness method were 


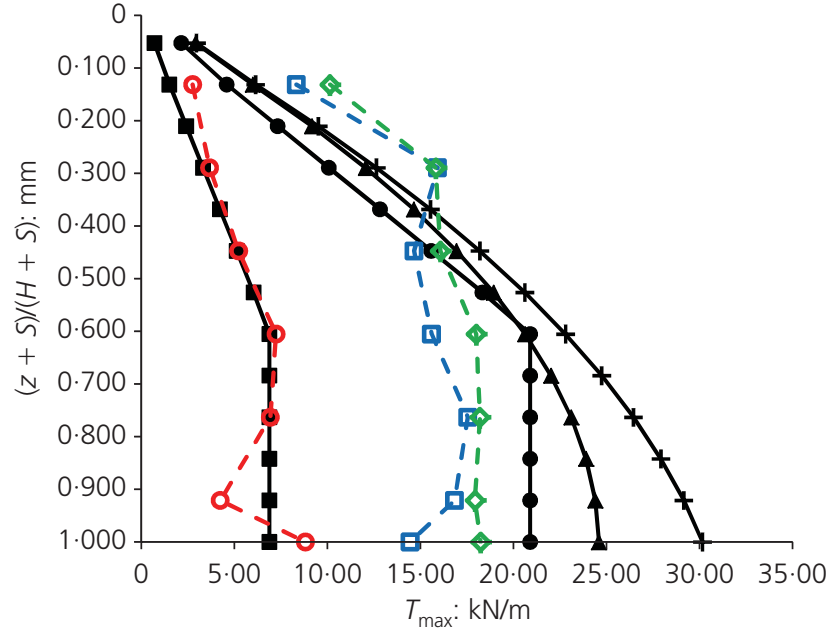

(a)
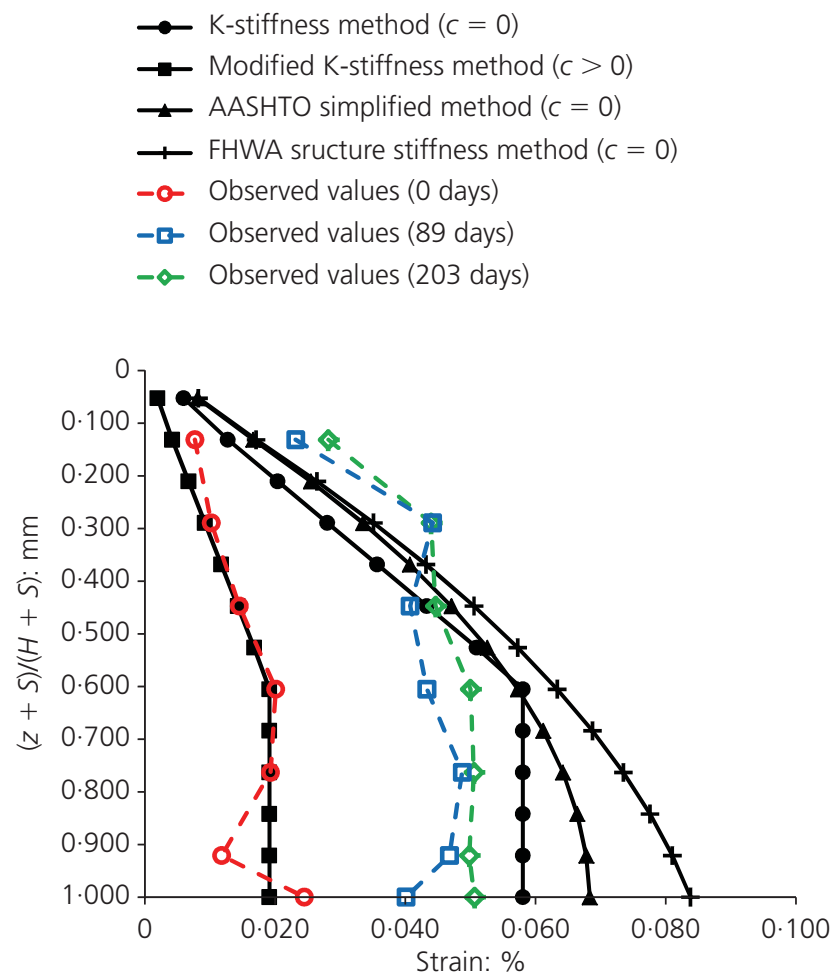

(b)

Figure 19. Measured and predicted reinforcement load and strain for SWG embankment with poor-quality backfills (weathered clay) on soft ground (Shivashankar, 1991).

(a) Comparison of measured and predicted reinforcement load;

(b) comparison of measured and predicted reinforcement strain.

SWG, steel wire grid

higher than that of the AASHTO simplified method. Conservative findings have been shown in the comparison of reinforcement loads and strains using limit equilibrium methods on load discrepancies between measured and predicted values from embankment case histories.

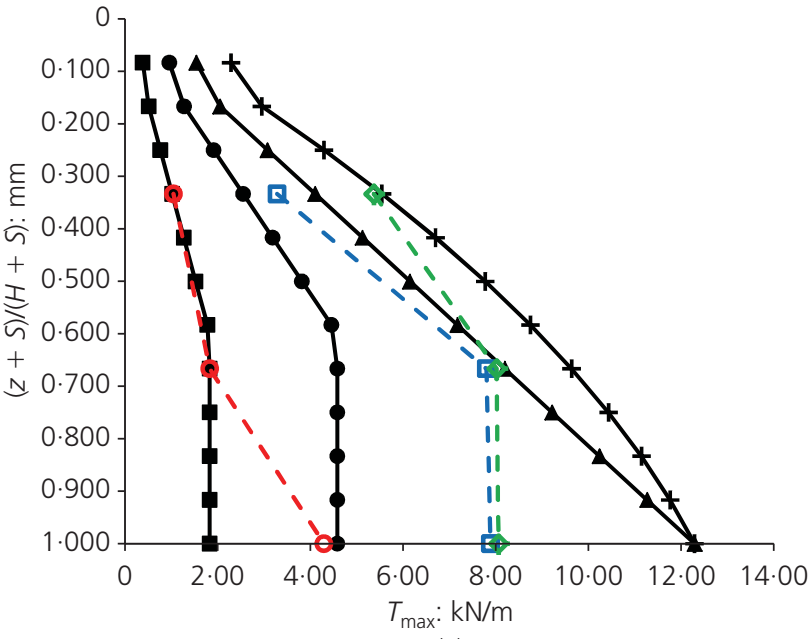

(a)

$\rightarrow$ K-stiffness method $(c=0)$

$\rightarrow$ Modified K-stiffness method $(c>0)$

$\rightarrow$ AASHTO simplified method $(c=0)$

- FHWA structure stiffness method $(c=0)$

-o- Observed values (15 days)

-a- Observed values (120 days)

$-\infty$ Observed values (180 days)

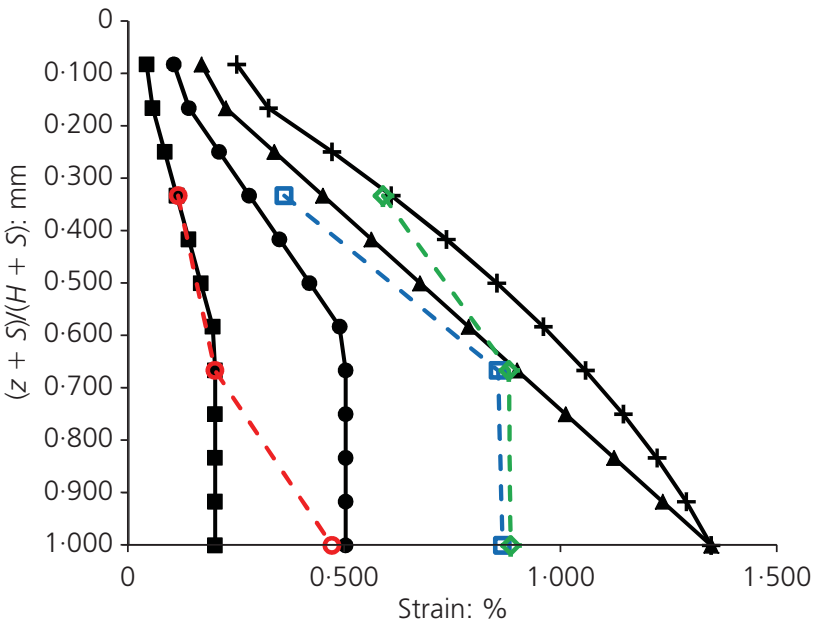

(b)

Figure 20. Measured and predicted reinforcement load and strain for HWG (PVC-coated) embankment on soft ground (Voottipruex, 2000). (a) Comparison of measured and predicted reinforcement load; (b) comparison of measured and predicted reinforcement strain. HWG, hexagonal wire-reinforced grid

Analysing the internal behaviour of embankment case histories in terms of reinforcement loads, it is apparent in Figures 17 to 20 that the majority of the distribution and magnitude of reinforcement loads are in good agreement with the modified K-stiffness method except for some cases where the embankment facing was not vertical as in the case of geogrid-reinforced embankment by 
Nualkliang (2011). Nevertheless, it can be seen in the figures that the measured maximum reinforcement loads immediately after construction are within the original K-stiffness method reinforcement load envelope. At the bottom reinforcement layer where most of the maximum reinforcement loads in the embankment occur, the measured reinforcement loads were consistently higher than the load predicted using the modified K-stiffness method due to the effect of ground settlement at the bottom reinforcement layer. Consequently, the increase in the magnitude of reinforcement load at the bottom layer is proportional to the increase in ground settlement values.

\subsection{Different periods after construction}

At different periods after construction, especially for embankment case histories on soft ground foundation, the reinforcement load especially near the base increased with time as consolidation settlements occurred (Figures 17 to 20). In the case of SWGreinforced embankment (Shivashankar, 1991), the final measured reinforcement loads after the ground settled considerably and generally approached the values predicted by the original Kstiffness method starting from normalised depth, $(z+S) /(H+S)$, value of 0.3 to the base of the reinforced soil structure. For this embankment, the predicted loads using the original K-stiffness method, the AASHTO simplified method and FHWA structure stiffness method relatively agreed with each other from the topmost reinforcement layer to normalised depth value of $0 \cdot 60$. The same behaviour was observed for the embankment reinforced with hexagonal wire mesh reinforcements and backfilled with silty sand (Voottipruex, 2000) where, depending on the magnitude of consolidation settlements, the measured loads tend to approach the predicted values of the original K-stiffness method and extend further towards the values predicted by limit equilibrium methods as magnitudes of consolidation settlements continue to increase considerably.

\section{Further modification of the K-stiffness method for reinforced embankments on soft and hard ground}

The reinforced embankment case histories considered in this study were evaluated for their performance immediately after construction and at different periods after completion of the embankment where consolidation settlements contributed to the responses of the reinforced embankment in terms of distribution and magnitude of reinforcement loads as well as the lateral movement of the embankment facing. Current design methods have not been calibrated and evaluated for possible post-construction load increase. Thus, further modification of the K-stiffness method to include the settlement factor in addition to the cohesion factor is proposed. The relevant parameters obtained from the case histories for cohesive-frictional backfill soils and foundations with settlements are summarised in Table 5. The zinc-coated hexagonal wire mesh-reinforced embankment section studied by Voottipruex (2000) were excluded from the analysis because these embankments were judged to be poorly based on the criterion set by Miyata and Bathurst (2007a) that the strain rates in the reinforcements should decrease as the time after the construction increases. This statement is particularly applicable in this study for periods after the completion of the embankment when the ground has already attained considerable consolidation settlement. At the end of the primary consolidation of the foundation, the increase in strain rates of the reinforcements in the embankment should decrease as the ground attains stability.

From the maximum measured reinforcement load in the embankment for each period after the construction for the reinforced embankment case histories, the settlement factors, $\Phi_{\mathrm{s}}$, were backcalculated. Subsequently, the back-calculated settlement factors were plotted against the normalised settlement ratio expressed as $S / \gamma H$ as shown in Figure 21 for geogrid and hexagonal wire mesh, and metallic reinforcements, respectively. Taking into consideration the type of reinforcements used in the embankments and the range of values for the normalised settlement ratio, $S / \gamma H$, the settlement factor, $\Phi_{s}$, is expressed as follows in Equations 5 and 6

For geogrid- and hexagonal wire mesh-reinforced embankments.

For $S / \gamma H \leqslant 4 \cdot 00$

5. $\Phi_{\mathrm{s}}=1 \cdot 37(S / \gamma H)+0 \cdot 5$

For metallic-reinforced embankments.

For $S / \gamma H>4 \cdot 00$

6. $\Phi_{\mathrm{s}}=0.076(S / \gamma H)+2 \cdot 00$

where $\Phi_{\mathrm{s}}$ is the foundation settlement factor, $S$ is the magnitude of foundation settlement at the ground surface $(\mathrm{mm})$ at any particular period, $\gamma$ is the unit weight of backfill material $\left(\mathrm{kN} / \mathrm{m}^{3}\right)$ and $H$ is the height of the reinforced embankment.

As observed in Figures 17 to 20, the maximum measured reinforcement load in the embankment generally occurred at the base of the reinforced soil embankment. Consequently, the load distribution factor, $D_{\text {tmax }}$, for geogrid- and hexagonal wire mesh-reinforced soil structures was further modified based on this observation. Subsequently, a uniform value of $D_{\text {tmax }}$ equal to 1.0 was used starting from the normalised depth, $(z+S) /(H+S)$, value of 0.4 to the base of the reinforced soil structure where the normalised depth, $(z+S)$ / $(H+S)$, value is equal to $1 \cdot 0$. The $D_{\text {tmax }}$ for the metallic-reinforced soil structure was not modified and the load distribution factor still applies. Finally, with the further modifications of the K-stiffness method, the maximum reinforcement load per unit width of the embankment is expressed in Equation 7

7. $T_{\max }=\frac{1}{2} K \gamma(H+S) S_{\mathrm{v}} D_{\mathrm{tmax}} \Phi_{\mathrm{g}} \Phi_{\text {local }} \Phi_{\mathrm{fs}} \Phi_{\mathrm{fb}} \Phi_{\mathrm{c}} \Phi_{\mathrm{s}}$ 


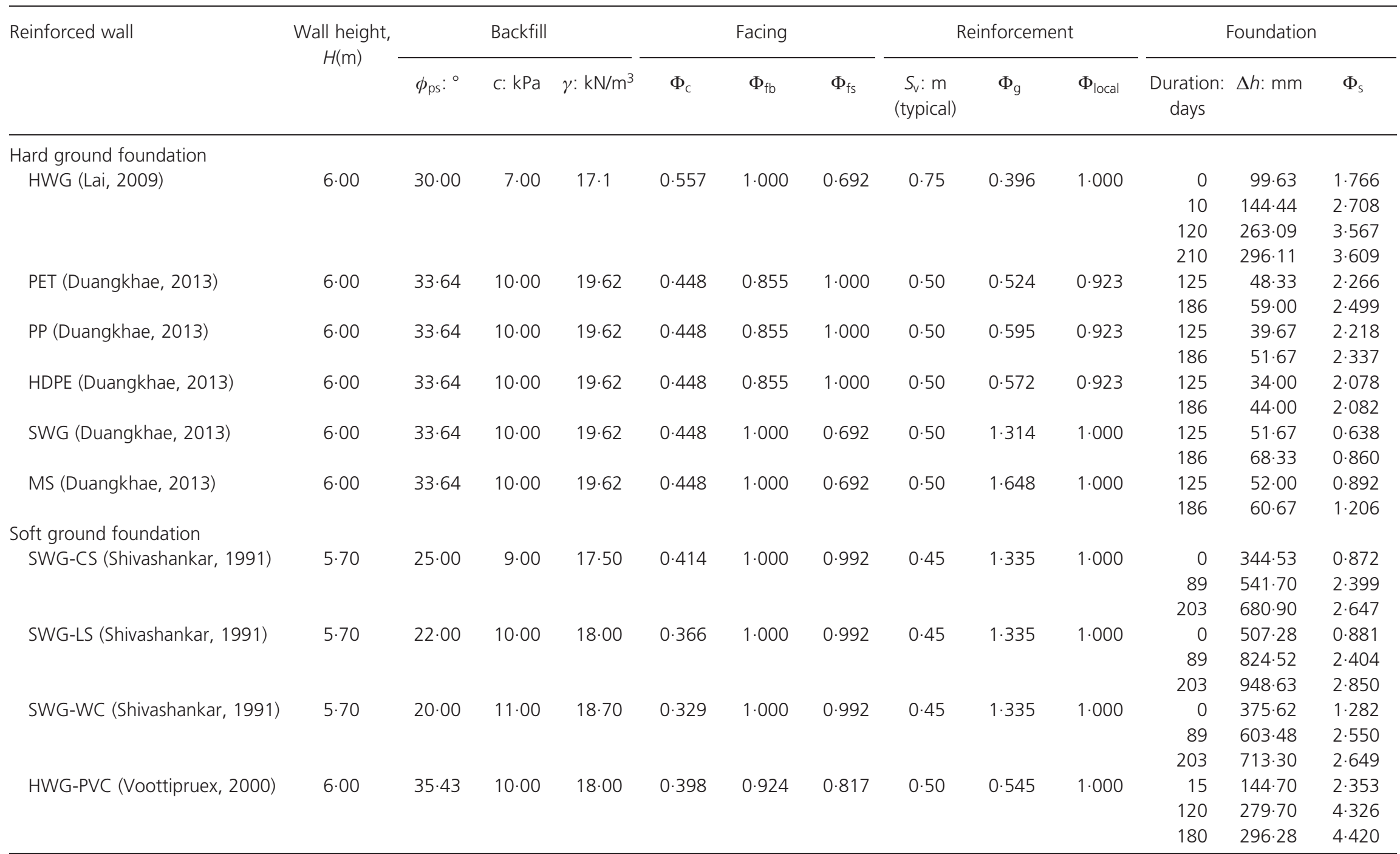

CS, clayey sand; HDPE, high-density polyethylene; HWG, hexagonal wire-reinforced grid; LS, lateritic soil; MS, metallic strip; PET, polyester; PP, polypropylene; SWG, steel wire grid;

WC, weathered clay 


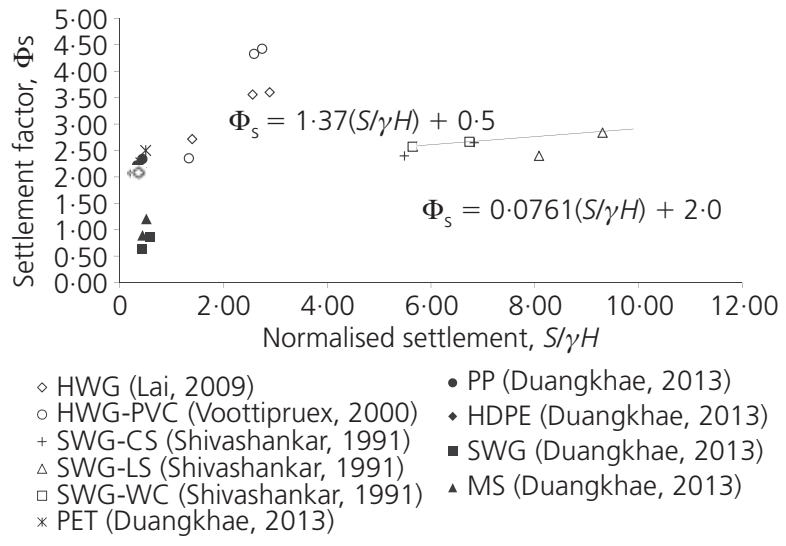

Figure 21. Back-calculated settlement factor, $\Phi_{s}$, for geogrid and hexagonal wire mesh grid (HWG) reinforcements plotted against normalised settlement ratio, $S / \gamma H$

where the terms have been defined previously.

\section{Validation of the further modification of the K-stiffness method}

Comparisons were made on the performances on the prediction of reinforcement loads in the embankment immediately after construction and at different periods after the completion of the embankments between the original K-stiffness method, the modified K-stiffness method and the further modified K-stiffness method. To verify the validity of the abovementioned prediction methods, the values of the maximum reinforcement load in the embankments were recalculated and plotted against the measured maximum reinforcement loads in the embankments immediately after construction and at different durations after construction. A $45^{\circ}$ line representing a bias value of 1.0 was also plotted to serve as the boundary between regions of overpredicted and underpredicted values of reinforcement loads. The original K-stiffness method tends to overpredict the magnitude of reinforcement load when the foundation settlement is still minimal but more likely to underpredict the magnitude of reinforcement load at large foundation settlements. This observation is also supported by the quantitative assessment of the maximum reinforcement loads in the embankment, $T_{\mathrm{mxmx}}$, immediately after construction and at the final duration where considerable settlements were experienced by the embankments.

Considering its performance at any duration after the construction of the embankment, an acceptable mean of bias values for $T_{\mathrm{mxmx}}$ equal to 0.98 was computed but with a relatively higher value of coefficient of variation (COV) equal to $49 \cdot 58 \%$ compared to $19 \cdot 40 \%$ for the further modified K-stiffness method as shown in Table 6 .

In the case of the modified K-stiffness method with only the cohesion factor added, it was found that the majority of the points are located below the $45^{\circ}$ line (Figure 22). This means that the maximum reinforcement loads in the embankment were constantly underpredicted as the time and magnitudes of ground settlements increased. Immediately after the completion of the embankment, the modified K-stiffness method reasonably predicted the values of the maximum load in the reinforcement layer, $T_{\max }$, but underpredicted the magnitude of maximum reinforcement load in the embankment, $T_{\mathrm{mxmx}}$, especially for geosyntheticand hexagonal wire mesh-reinforced embankments where the bottom reinforcement layer was largely affected by a small change in the magnitudes of foundation settlements as shown in Figures 17 to 20. However, for the further modified K-stiffness method with separate cohesion and settlement factor, a good agreement between the maximum measured reinforcement loads and the recalculated maximum reinforcement load values in the embankment was observed in which the majority of the points are situated close to the $45^{\circ}$ line (Figure 23). The recalculated reinforcement loads were obtained by applying the aforementioned further modifications of the K-stiffness method as discussed in the previous section. The further modified K-stiffness method presents a flexible approach to predicting the magnitudes of load in the reinforcements of the embankment. This method considers the post-construction load increase in the reinforcements due to consolidation settlements of the foundation. Moreover, at different durations after the construction, a mean of bias values of 0.91 with $\mathrm{COV}$ of $19.40 \%$ was obtained taking into account the magnitudes of the maximum reinforcement load in the embankment, $T_{\mathrm{mxmx}}$, as presented in Table 6 . The prediction method is considered to be relatively accurate if the value of the mean of bias is nearly equal but a little less than 1 while keeping the value of coefficient of variation (COV) minimum. Therefore, the further modified K-stiffness method, which effectively incorporated the effect of post-construction load increase due to foundation settlement, can be efficiently adopted to estimate the reinforcement loads for reinforced embankment backfilled with cohesive-frictional soils on soft and hard ground foundation.

\begin{tabular}{|c|c|c|c|c|}
\hline \multirow[t]{2}{*}{ Bias $^{a}$ parameter } & \multirow{2}{*}{$\begin{array}{c}\text { Number } \\
\text { of data } \\
\text { points }\end{array}$} & \multicolumn{3}{|c|}{ K-stiffness method } \\
\hline & & Original & $\begin{array}{l}\text { Modified } \\
\qquad\left(\Phi_{c}\right)\end{array}$ & $\begin{array}{c}\text { Modified } \\
\left(\Phi_{\mathrm{c}} \text { and } \Phi_{\mathrm{s}}\right)\end{array}$ \\
\hline Column & 1 & 2 & 3 & 4 \\
\hline Mean $T_{\mathrm{mxmx}}$ & 26 & 0.98 & $2 \cdot 24$ & 0.91 \\
\hline $\operatorname{COV} T_{m \times m x}: \%$ & 26 & $49 \cdot 58$ & $44 \cdot 70$ & $19 \cdot 40$ \\
\hline
\end{tabular}

a Bias refers to ratio of measured to predicted values; $T_{\mathrm{mxmx}}$, maximum reinforcement load in the embankment; COV, coefficient of variation of bias values

Table 6. Quantitative assessment on the improvement on reinforcement load prediction of modified K-stiffness method after introduction of settlement factor, $\Phi_{\mathrm{s}}$ 


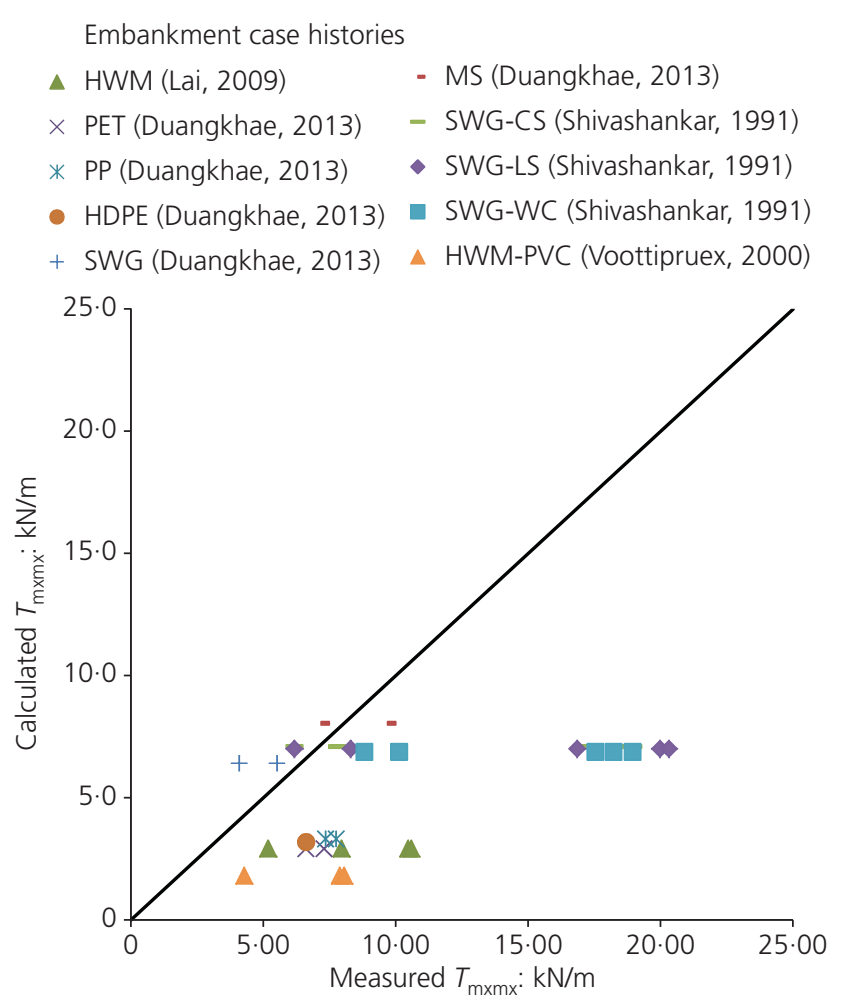

Figure 22. Measured vaue plotted against calculated maximum reinforcement load in the embankment, $T_{m \times m x}$, using modified $\mathrm{K}$-stiffness method (with cohesion factor) at different durations of the embankment

\section{Conclusions}

In this study, current reinforcement load prediction methods have been presented and applied to assess the data obtained from four full-scale and fully instrumented reinforced embankments previously studied at AIT. Two of these reinforced embankments were constructed on hard ground while the rest were constructed on soft ground. These embankments were reinforced with steel wire grids, metallic strips, hexagonal wire mesh and geogrid materials, particularly PET, PP and HDPE. From the results of the analyses performed on the embankment case histories, the following conclusions were drawn.

(a) The rate of increase in the magnitudes of the reinforcement load with respect to time was minimal for the embankments on hard ground but significant for the embankments on soft ground. The increase in the magnitude of the measured reinforcement loads, especially at the base of the embankment, is therefore proportional to the increase in value of ground settlement.

(b) The values of the reinforcement load predicted by limit equilibrium methods (AASHTO simplified method and FHWA structure stiffness method) were consistently higher than those of the K-stiffness method (original and modified) and the measured loads for all cases of embankments on hard

\section{Embankment case histories}

4 HWM (Lai, 2009) - MS (Duangkhae, 2013)

$\times$ PET (Duangkhae, 2013) - SWG-CS (Shivashankar, 1991)

* PP (Duangkhae, 2013) • SWG-LS (Shivashankar, 1991)

HDPE (Duangkhae, 2013) — SWG-WC (Shivashankar, 1991)

+ SWG (Duangkhae, 2013) \ HWM-PVC (Voottipruex, 2000)

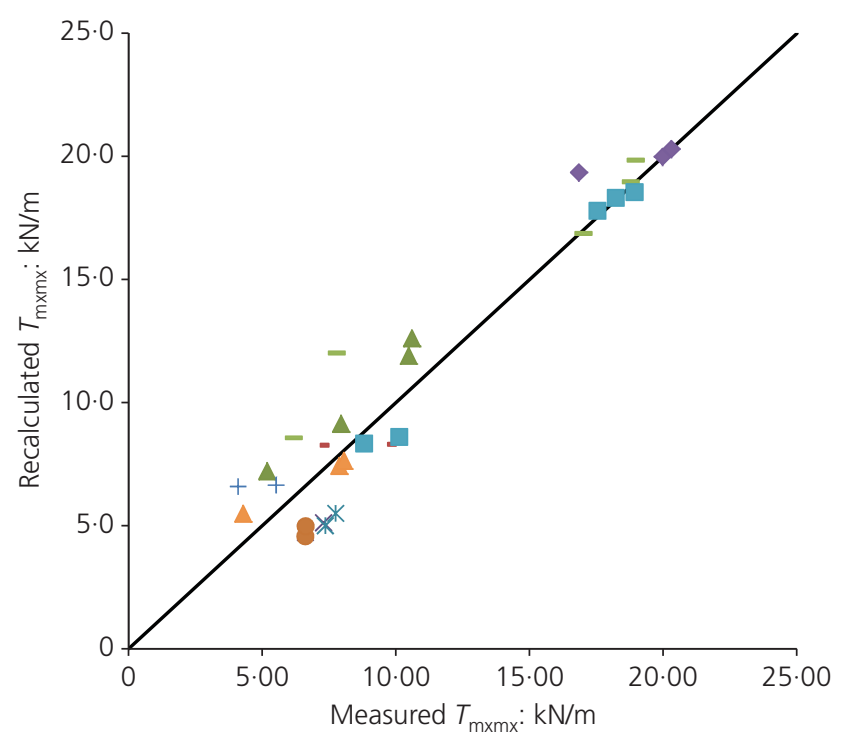

Figure 23. Measured vaue plotted against recalculated maximum reinforcement load in the embankment, $T_{m \times m x}$, using modified K-stiffness method (with cohesion and settlement factors) at different durations of the embankment

and soft ground immediately after construction and at any periods after the completion of the embankment. Although the predicted loads were almost similar in distribution and magnitude, the FHWA structure stiffness method resulted in a more conservative prediction than the AASHTO simplified method.

(c) The magnitudes of the reinforcement load predicted using the original K-stiffness method were constantly higher than the measured loads immediately after construction for all embankment case histories on soft and hard ground regardless of the values of reinforcement stiffness but predictions were observed to be inconsistent with the measured loads as ground settlement increased.

(d) The modified K-stiffness method performed well for metallicreinforced embankment on soft and hard ground immediately after construction but underpredicted the magnitudes of the maximum reinforcement load at any duration after construction. For the case of geogrid- and hexagonal wire mesh-reinforced embankment, the modified K-stiffness method consistently underpredicted the values of the maximum reinforcement load for embankments on soft and hard ground.

(e) The load distribution factor, $D_{\text {tmax }}$, for geogrid and hexagonal wire mesh reinforcement was modified where a uniform 
value of 1.0 was proposed starting from the normalised depth, $(z+S) /(H+S)$, value of $0 \cdot 4$ to the base of the reinforced embankment as the maximum reinforcement load in the embankment generally occurred at the base of the reinforced soil structure.

( $f$ ) Further modification of the K-stiffness method was proposed by introducing a separate settlement factor, $\Phi_{\mathrm{s}}$, on the modified K-stiffness method in order to take into account the effect of foundation settlement on the magnitude and distribution of reinforcement load.

\section{REFERENCES}

AASHTO (American Association of State Highway and Transportation Officials) (2002) Standard specifications for highway bridges, 17 edn. AASHTO, Washington, DC, USA.

Allen TM and Bathurst RJ (2002) Soil reinforcement loads in geosynthetic walls at working stress conditions. Geosynthetic International 9(5-6): 525-526.

Allen TM, Bathurst RJ, Holtz RD, Walters D and Lee WF (2003) A new working stress method for prediction of reinforcement loads in geosynthetic walls. Canadian Geotechnical Journal 40(5): 976-994.

Allen TM, Bathurst RJ, Holtz RD, Walters D and Lee WF (2004) New method for prediction of loads in steel reinforced soil walls. Journal of Geotechnical and Geoenvironmental Engineering 130(11): 1109-1120.

Bathurst RJ, Miyata Y, Nernheim A and Allen MT (2008) Refinement of K-stiffness method for geosynthetic reinforced soil walls. Geosynthetics International 15(4): 269-295.

Bergado DT and Teerawattanasuk C (2008) 2D and 3D numerical simulations of reinforced embankments on soft ground. Geotextiles and Geomembranes 26(1): 39-55.

Bergado DT, Sampaco CL, Shivashankar R et al. (1991a) Performance of welded wire wall with poor quality backfills on soft clay. ASCE Geotechnical Engineering Congress, Boulder, Colorado, USA, 909-922.

Bergado DT, Shivashankar R, Sampaco CL, Alfaro MC and Anderson LR (1991b) Behavior of welded-wire wall with poor quality cohesive-frictional backfills on soft Bangkok clay. Canadian Geotechnical Journal 28(6): 860-880.

Bergado DT, Chai JC and Mirura N (1995) FE analysis of grid reinforced embankment systems on soft Bangkok clay. Computers and Geotechnics 117(4): 447-471.

Bergado DT, Teerawattanasuk C, Youwai S and Voottipruex $\mathrm{P}$ (2000) FE modeling of hexagonal wire reinforced embankment on soft clay. Canadian Geotechnical Journal 37(6): 1209-1226.

Christopher BR, Gill SA, Giroud SP et al. (1990) Reinforced soil structures (I). Design and Construction Guidelines. FHWA RD-89-043, Washington DC, USA.

Duangkhae S (2013) Laboratory and field behavior of reinforced wall/embankment using various reinforcements and facing systems. DEng dissertation No. GE-12-03. Asian Institute of Technology, Bangkok, Thailand.
Jones CJFP (1996) Earth and Soil Structures Reinforcement. Thomas Telford, London, UK,379 pp.

Jones CJFP and Edwards LW (1980) Reinforced earth structures on soft foundations. Geotechnique 30(2): 207-211.

Lai YP (2009) Performance and Behavior of Full Scale Reinforced Soil Embankment/Wall on DMM Improved Foundation. DEng dissertation No. GE-08-02. Asian Institute of Technology, Bangkok, Thailand.

Lai YP, Bergado DT, Lorenzo GA and Duangchan T (2006) Fullscale reinforced embankment on deep jet mixing improved ground. Ground Improvement 10(4): 153-164.

Miyata Y and Bathurst RJ (2007a) Development of the K-stiffness method for geosynthetic reinforced soil walls constructed with $\mathrm{c}-\phi$ soils. Canadian Geotechnical Journal 44(12): 1391-1416.

Miyata Y and Bathurst RJ (2007b) Evaluation of K-stiffness method for vertical geosynthetic reinforced granular soil walls in Japan. Soils and Foundations 47(2): 319-335.

Nualkliang M (2011) Behavior of MSE Wall/Embankment with Geogrid and Metallic Reinforcements on Hard Foundation. MEng thesis No. GE-10-05. Asian Institute of Technology, Bangkok, Thailand.

Shivashankar R (1991) Behavior of Mechanically Stabilized Earth (MSE) Embankment with Poor Quality Backfills on Soft Clay Deposits, Including a Study of the Pullout Resistances. DEng dissertation No. GT-90-03. Asian Institute of Technology, Bangkok, Thailand.

Tin N (2009) Factors Affecting The Kinked Steel Grid Reinforcement snd Modification of K-Stiffness Method in MSE Structures on Soft Ground. MEng thesis No. GE-08-03. Asian Institute of Technology, Bangkok, Thailand.

Tin N, Bergado DT and Voottipruex P (2011) Modification of K-stiffness method in MSE structures on soft ground. Geosynthetic International 18(5): 304-321.

Voottipruex P (2000) Interaction of Hexagonal Wire Reinforcement with Silty Sand Backfill Soil and Behavior of Full Scale Embankment Reinforced with Hexagonal Wire. DEng dissertation No. GE-99-1. Asian Institute of Technology, Bangkok, Thailand.

\section{WHAT DO YOU THINK?}

To discuss this paper, please email up to 500 words to the editor at journals@ice.org.uk. Your contribution will be forwarded to the author(s) for a reply and, if considered appropriate by the editorial panel, will be published as a discussion in a future issue of the journal.

Proceedings journals rely entirely on contributions sent in by civil engineering professionals, academics and students. Papers should be 2000-5000 words long (briefing papers should be 1000-2000 words long), with adequate illustrations and references. You can submit your paper online via www.icevirtuallibrary.com/content/journals, where you will also find detailed author guidelines. 